\title{
Free and freed Afro-descendants and political equality in Portuguese America.Change of status, slavery and Atlantic perspective (1750-1840) ${ }^{1}$
}

DOI

http://dx.doi.org/10.1590/2236-463320151101

Luiz Geraldo Silva

Universidade Federal do Paraná
This article is part of a wider project entitled Politica e sociedade nas Américas ibéricas: independência e formação do Estado e da nação no Brasil e no Rio da Prata (1750-1850), and is supported by CAPES and by the MINCYT (Argentina). Translated by Vivian Bosch, whom we thank for.

\begin{abstract}
I propose in this article that free and freed Afro-descendants of three colonial empires of the modern era, the Spanish, the Portuguese and the French, have developed differentiated demands in different procedural steps: the ones that aimed privileges during the old or oligarchic type society, and the ones which demanded political and civil equality during the formation process of the democratic and representative type society. I analyze this aspect from connection plans, structural regularities and recurrences that suggest that the social position of those individuals and their social group in the referred colonial empires is consequence, on the one hand, of diachronic aspects relating to slavery and, on the other hand, synchronous social processes, own to the specific temporality of the 18th and 19th Centuries, such as the transition from one to another kind of society. To do so, I use concepts drawn from sociology and anthropology, such as the social representation and the freedom-slavery continuum.
\end{abstract}

\section{Resumo}

Proponho neste artigo que afrodescendentes livres e libertos de três impérios coloniais da era moderna, o espanhol, o português e o francês, elaboraram demandas diferenciadas em distintas etapas processuais: as que visavam privilégios durante a sociedade de tipo antigo, ou oligárquico, e as que exigiam igualdade política e civil durante o processo de formação da sociedade de tipo democrático e representativo. Analiso este aspecto a partir de planos de conexões, regularidades estruturais e recorrências que sugerem que a posição social daqueles indivíduos e de seu grupo social nos referidos impérios coloniais decorria, por um lado, de aspectos diacrônicos relativos ao escravismo e, por outro lado, de processos sociais sincrônicos, próprios da temporalidade específica dos séculos XVIII e XIX, tal como o de transição de um a outro tipo de sociedade. Para tanto, utilizo conceitos retirados da sociologia e da antropologia, como os de figuração social e continuum liberdade-escravidão.

\section{Keywords}

Spanish Empire - Portuguese Empire - French Empire - Free and Freed Afro-descendants - Eighteenth Century - Nineteenth Century

Palavras-chave

Império espanhol - Império português - Império francês Afrodescendentes livres e libertos - Século XVIII - Século XIX 
SILVA, Luiz Geraldo; SOUZA, Fernando Prestes. Negros apoyos. Milicianos afrodescendientes, transición política y cambio de estatus en la era de las independencias (capitanías de São Paulo y Pernambuco, Brasil, 1790-1830). Nuevo MundoMundos Nuevos, v. 2, 2014, p. 1-25; SILVA, Luiz Geraldo. Gênese das milícias de pardos e pretos na América portuguesa: Pernambuco e Minas Gerais, séculos XVII e XVIII. Revista de Historia (USP), v. 169, n. 2, 2013, pp. 111-144; SILVA, Luiz Geraldo. Negros de Cartagena y Pernambuco en la era de las revoluciones atlánticas: trayectorias y estructuras (1750-1840). Anuario Colombiano de Historia Social y de la Cultura, v. 40, n. 2, 2013, p. 211-240.

PATERSON, Orlando. Slavery and Social Death: A Comparative Study. Cambridge: Harvard University Press, 1982, pp. 259-261; BUCKLEY, Roger N. Slave or freedman: the question of the legal status of the British West India soldier, 1795-1807. Caribbean Studies, vol. 17, n. 3-4, 1978, pp. 83-113.

This expression comes from RUSSELL-WOOD, A. J. R. 2005. Escravos e libertos no Brasil colonial. Rio de Janeiro: Civilização Brasileira, p. 288.
I

I have highlighted in recent works that the analysis of actions and mental representations of individuals and social groups of the lowest level throughout the process of transition from the old or oligarchic type society to the democratic and representative type requires approaches that incorporate concepts and notions from sociological and anthropological theories, as well as the Atlantic and long-term perspectives. ${ }^{2}$ Pursuing this goal, I have insisted on the use of concepts such as social figuration and freedom-slavery continuum, as well as highlighted the importance of paying attention to connection plans, structural regularities and recurrences that approach experiences, actions and mental representations of free and freed Afro-descendants - as I prefer to designate them analytically, I believe, more accurately - of all colonial empires of the modern era marked by slavery. Despite their flagrant diversity, the specific social representations that exist within the comprehensive social figurations of the Spanish, Portuguese and French Empires produced social positions and status change processes related to that social group that, in "the era of revolutions", allowed to claim simultaneously political equality in relation to other individuals and social groups in their respective societies. This did not occur, however, in the case of the British Empire, whose specific social representations of the Caribbean and North America - and not their "culture" or the "racism" of individuals of the highest level - did not produce that social position in "the era of revolutions" as a result of the extremely limited access to manumission, to the hand labor market and to social functions identified with the militias. ${ }^{3}$ Thus, the British Empire's comprehensive social representation is deliberately out of this analysis model.

I want to highlight two central aspects in this article that connect the experiences of free and freed Afro-descendants under the Portuguese, Spanish and French Colonial Empires, which illuminate and clarify the nature of their actions and representations considerably throughout the process of transition from old or oligarchic type society to the democratic and representative type. In the first place, I suggest that this social group expressed radically different demands in specific contexts of the old or oligarchic type society and the democratic and representative type society. Although these demands can be seen in a connected and processual form, they show, in old-style society, the obtaining of privileges, forums, franchises and exemptions, while in the representative type society they required mostly political equality, that is, citizenship based on the enjoyment of civil and political rights common to all individuals with legal and political status of "free man". Furthermore, it is worth mentioning that, in a transitional phase, specific individuals and social groups can, at the same time, assign value and meaning to their lives as much coming from the old or oligarchic type society, or from the new social configuration of democratic and representative type in process of establishment. This, however, cannot be interpreted as "ambiguity", as if these individuals and their social group lived on a limb or in a "social and racial 'no man's land'". In so far as it does not problematize the specific social position of free and freed Afro-descendants in the social figurations which they were part of and does not situate them in the freedom-slavery continuum, historiography, in general, suggests that this ambiguity refers primarily to an allegedly erratic behavior of that social group in the face of the one formed by the slaves. David Geggus, for example, argues that the "situation" of the free 
5

GEGGUS, David P. Haitian revolutionary studies. Bloomington: Indiana University Press, 2002, p. 93. This same point of view can be found in KRAAY, H. Race, State and armed forces in independence-era Brazil (Bahia, 1790s-1840s). Stanford: Stanford University Press, 2001, pp. 88-105.

6

See, for example, Jacinto Roque da Rocha,

Capitão de Campo da Freguesia do Cabo. Arquivo Público Estatual Jordão Emerenciano (Recife), série Patentes Provinciais, vol. 9, fls. 131v-132, Recife, 17 November 1797; Livro para matrícula e registro das esquadras dos capitães do mato. Arquivo Público Mineiro, série Câmara Municipal de Sabará, CMS-081, 1788; DANTAS, Mariana L. R. "For the benefit of the common good": Regiments of caçadores do mato in Minas Gerais, Brazil. Journal of Colonialism and Colonial History, vol. 5, n. 2, 2004.

7

The notion of "social or group cohesion" that I use here comes from ELIAS, Norbert; SCOTISON, John I., The established and the outsiders. Sociology of power relations from a small community. Rio de Janeiro: Jorge Zahar Editor, 2000, pp. 21-25, 178-179.

8

PATTERSON, Orlando. 0p. Cit., p. 248 and KOPYTOFF, I. Slavery. Annual Review of Anthropology. Vol. 11, 1982, pp. 207-230. The concept of freedom-slavery continuum was formulated from historic sources from ancient world by FINLEY, Moses. Entre a escravatura e a liberdade. In: ANNEQUIN, J. et. al. (org.). Formas de exploração do trabalho e relações sociais na Antiquidade clássica. Lisboa: Estampa, 1978, pp. 89-109. However, such concept was proposed analitically by MIERS, Suzanne; KOPYTOFF, Igor. African "slavery" as an institution of marginality. In: MIERS, Suzanne; KOPYTOFF, Igor (orgs.). Slavery in Africa. Historical and anthropological perspectives. Madison: The University of Wisconsin Press, 1979, pp. 3-81. About the concepto f sóciodynamics of stigmatization, see ELIAS, Norbert; SCOTSON, John L. Op. Cit, pp. 24-32.

9

The concept of social representation was formulated by ELIAS, Norbert. Involvement and detachment. Studies on sociology of knowledge. Lisbon: Dom Quixote, 1997, pp. 54-63; ELIAS Norbert. Introduction to sociology. Lisbon: Edições 70, 2005, pp. 143-145; Elias, Norbert. Written \&t essays. Rio de Janeiro: Jorge Zahar Ed., 2006, pp. 25-27. A more recent discussion about this concept was proposed by DUNNING, Eric; HUGHES, Jason. Norbert Elias and modern Sociology. Knowledge, interdependence, power, process. London: Bloomsbury Publishing, 2013, pp. 50-75.

10

ELIAS, Norbert e SCOTSON, John L. Op. Cit, p. 32. and freed Afro-descendants from Saint-Domingue "was deeply ambiguous. Free color men were often accused of harboring fugitive slaves, but as they composed half of the militia and almost all rural police, they were also largely responsible for the recapture of fugitives".

However, the representations they made about themselves, as well as those that the other social groups made about them, are structurally consistent concerning the social position that free and freed Afro-descendants occupied in the freedom-slavery continuum existing in the social slave representations, in which many of their individuals not only become lords of slaves, but also acquire social functions linked to repression to mocambos and quilombos, as field captains and militiamen supported by the Spanish, Portuguese and French monarchies. ${ }^{6}$ Furthermore, in a transitional phase, which can also be understood in a consistent and structural form, ambivalent propositions are expressed not only by the social group here in question, but by all individuals and social groups affected by this process. Before, I propose that free and freed Afro-descendants constituted a social group marked by strong social cohesion, which is manifested clearly through the rich empirical material produced by it over the 18th and 19th Centuries. In this, they expressed their demands according to the social figurations of which they were part, as well as, and especially, marked their differences both in relation to individuals and social groups of the highest level as to the slaves.?

Secondly, I propose that individuals and social groups in question were, within their respective social representations, in a specific social position and status, which, ultimately, was due to the nature of slavery. It was therefore a sociologically, and not racially determined social position, as historiography has insisted in recent years. In my view, this emphasis on explanations of racial type stems from the fact that historians do not operate, on the one hand, with concepts and notions from the general theory of slavery - which encapsulates slave societies of the ancient or modern world, were these Asian, African or Westerners - and, on the other hand, with concepts arising from sociological theory - such as the socio-dynamics of stigmatization and freedom-slavery continuum, which I believe are essential to the proposition of this analysis problem. ${ }^{8}$ Furthermore, these aspects can only be acquired properly if they are treated from a figurational perspective, that is, that contemplates the relations of interdependence and social positions of all individuals and groups who conformed to the old or oligarchic type societies and the democratic and representative types. ${ }^{9}$

The stigma of collective disgrace imputed to free and freed Afrodescendants in old or oligarchic type societies through contemporary concepts like mechanical defect were the reverse of notions as honor and quality, self-applied to the oligarchical groups, were these ennobled or not. In all relations between established social groups and outsiders marked by an enormous differential of power retention, aversion, contempt and hatred devoted by established groups to outsiders are generally directed to some peripheral aspect of these relationships so as to look away from what is central, that is, "the power differentials and the exclusion of the less powerful group of positions with greater potential to influence".10

Explaining the formal or informal impediments imposed to free and freed Afro-descendants in the French Caribbean, Hispanic America or Portuguese America contexts in strictly racial terms, historians have therefore underlined peripheral aspects and neglected what is central in their power 
11

In the case of Brazil see KLEIN, Herbert S., The Colored Freedmen in Brazilian Slave Society, Journal of Social History, vol. 3, n. 1, 1969 , pp. 30-52; in the case of the US, see essay of INGERSOLL, Thomas N. Free Blacks in a Slave Society: New Orleans, 1718-1812. William and Mary Quarterly, vol. 48, n. 2, 1991, pp. 173-200; in the case of Saint-Domingue, see works of ROGERS, Dominique. On the road to citizenship: the complex route to integration of the free people of color in two capitals of Saint-Domingue. In: GEGGUS, David P.; FIERING, Norman (orgs.). The World of the Haitian Revolution. Bloomington: Indiana University Press, 2009, pp. 65-78 and GARRIGUS, John D. Before Haiti: race and citizenship in French SaintDomingue. New York: Palgrave Macmillan, 2014.

\section{2}

GUEDES, Roberto. Ofícios mecânicos e mobilidade social: Rio de Janeiro e São Paulo (Sécs. XVII-XIX). Topoi, vol. 7, n. 13, 2006, pp. 379-423; GUEDES, Roberto. Livros paroquiais de batismo, escravidão e qualidades de cor (Santíssimo Sacramento da Sé, Rio de Janeiro, Séculos XVII-XVIII). In: FRAGOSO, João, et. al. (org.). Arquivos paroquiais e história social na América Lusa, séculos XVII e XVIII: métodos e técnicas de pesquisa na reinvenção de um corpus documental. Rio de Janeiro: Mauad $X_{\text {, }}$ 2014, pp. 131-149.

13

RIBEIRO, Gladys Sabina. 0 desejo da liberdade e a participação de homens livres pobres e "de cor" na independência do Brasil. Cadernos CEDES vol. 22, n. 58, 2002, p. 32; CARVALHO, Marcus J. M. de. Os negros armados pelos brancos e suas independências no Nordeste (1817-1848). In: JANCSÓ, István (org.), Independência: história e historiografia..., Op. Cit., p. 881-914.

14

PATTERSON, Orlando. Op. Cit, p. 247.

15

MIERS, Suzanne; KOPYTOFF, Igor. Op. Cit., pp. 3-7.

16

PATTERSON, Orlando. Op. Cit., p. 248. relations. So, as Afro-descendant individuals and social groups were moving away from captivity through the process of status change, approaching, thus, the status of "free" born, they were even more subject to face these impediments. The transition of the old, oligarchic type society, to the democratic and representative type, by eliminating the political prerogatives based on honor and especially on birth, showed outsiders the nature of the social impediments which had been imposed to them for Centuries on end, creating the possibility of their social emancipation. However, the maintenance of captivity, on the one hand, and of the racial rhetoric, on the other hand, kept them attached to peripheral aspects of their social and power relations.

\section{II}

Historiography has produced good monographic works on the social group constituted by the "freed" or "free men of color" from various American slave societies." These works analyze their levels of wealth, their social origins and their political demands, were these manifested within the old or oligarchic type society, or in the democratic and representative type. At the same time, recently, discussions and interpretations about their genesis and development in Portuguese America are_founded on dynamics of color rating systems, generally perceived through the use of serial sources associated with complex methodological procedures. ${ }^{12}$ However, when discussed from the point of view of politics, free and freed Afro-descendants are sometimes described as individuals dependent on oligarchies or lacking in "bourgeois liberal ideals".13

As I have already suggested, I intend to resume these problems diachronically in the light of conceptual and theoretical instruments available in the general theory of slavery that allow reflections beyond the stereotypes of the American plantation societies. The discussions about this theoretical and conceptual field help us understand adequately the fact that the social position of freedmen and their descendants in the frames of any slave society, ancient or modern, is, as I proposed earlier, sociologically determined. In fact, in all slave societies, were they Western, Asian or African, ancient or modern, the stigma of previous slavery is a central aspect in the determination of the social position of the freedmen. That is the reason why they are rarely "perceived as an equal" in a slave society even after obtaining the political-legal status of a free man, distinguishing mark which, moreover, is inherited by their descendants. ${ }^{14}$

It is essential, therefore, to situate the freedmen and their descendants in the slavery-freedom continuum, and have the idea of slavery as a process in mind. As Miers and Kopytoff observe, the slaves, in the Western view, constitute a social stratum, since slavery is seen from the same prism of concepts such as "class" and "caste", that is, as a static form of "social stratification". According to this image, "freedom" is understood as the antithesis of "slavery", and vice versa. What these authors propose, rather, is that slavery and freedom are parts of the same continuum, and not different concepts or "states" or, worse, opposites. ${ }^{15}$ As Patterson summarizes, "slavery was not a static institution. From the moment that the slave enters this status, changes begin to take place in their relation with their lord and with the rest of the community".16 Thus, the various statuses of slaves and freed are part of the same process, the same continuum, and are changeable intra and inter-generationally. Furthermore, he warns that one 
18

It is granted more to the said Ombudsmen to sentence Indians, Bastards, Carijós, mulattos and Blacks, in the atrocious crimes to the death penalty and be rapporteur Judges of the Justice Joint, as seen in the following order. Lisbon, October 20 1735. General information of the Captaincy of Pernambuco (1749). Anais da Biblioteca Nacional, vol. XXVIII, 1906, p. 456.

19

RAMINELLI, Ronald. "Los límites del honor". Nobles y jerarquias de Brasil, Nueva España y Peru, siglos XVII y XVIII. Revista Complutense de História de América, vol. 40, 2014, pp. 4568; RAMINELLI, Ronald. Impedimentos da cor. Mulatos no Brasil e em Portugal, c. 1640-1750. Vária História, vol. 28, n. 48, 2012, pp. 699-723; RUSSELL-W00D, A. J. R. Escravos e libertos..., Op. Cit., pp. 107-110.

\section{0}

Application of Captain Miguel Mendes de Vasconcelos and his son to King, D. João, requesting provision to serve as prosecutors of causes in the auditoriums of the city of Bahia, nevertheless being Brown. Overseas Historical Archive (Lisbon), Bahia (hereinafter AHU Correspondent Captaincy), cx. 77 document 6412. City of Bahia, September 231743.

21

Cases similar to that of Mendes de Vasconcelos are registered in the Application of Luis Martins Soares to the King, D. João, requesting provision of supernumerary applicant in the city of Bahia to enter the number and dispensing in accidents of brown colors in occasion of opposition. AHU-BA, box 79 document 6557 . City of Bahia, 17 June 1744 and Application of Paulo Coelho to King D. José I, requesting provision for his Brown color not to be an impediment to exercise any public function in any part of Brazil. Pernambuco. AHU$P E$, box 76 doc. 6377. Recife, 29 July 1754.

22

ELIAS, Norbert; SCOTSON, John L. Op. Cit., p. 32. should distinguish the "political-legal status" of the freed from what one might call "prestige ranking", that is, the respect with which they are seen by other people of their social figuration, especially the free. On the one hand, the acquisition of political-legal capacity, or the obtainment of political-legal status of "free man", does not imply full social acceptance, since in all slave societies, ancient and modern, regardless of "racial" type differences, the freedmen remain stigmatized by their previous link to captivity. ${ }^{17}$

Thus, the prestige ranking refers to the fact that in most of the slave societies freedmen and their descendants have some sort of disqualification, which, however, tends to be reduced inter-generationally. In any case, rare are the executive and administrative roles to which they are assigned in the ancient or modern world and, as occurred in old or oligarchic style Iberian colonial societies, as well as in other slave societies of the Atlantic world, free and freed Afro-descendants were forbidden to bear arms and use certain garments or adornments. Furthermore, in Portuguese America, special laws were recommended by the Overseas Council from 1735 on for the punishment of their crimes, ${ }_{18}^{18}$ at the same time that free and freed Afro-descendants were prevented legally from exercising certain trades, such as goldsmith, from joining military and religious orders and entering governance and leading institutions, as the Senate Chamber of the villages, in addition to being constantly limited in the exercise of the so called "liberal arts".19 In the mid-18th Century, for example, free Afro-descendants Miguel Mendes de Vasconcelos and his son of the same name, both residents in the Captaincy of Bahia, fulfilled the office of "attorneys of causes in the Auditoriums" acting "in the Relation and more courts of the city". The office they exercised makes it clear, therefore, how father and son had advanced in the process of changing status and in the prestige ranking within the social slave representation of Bahia, distancing themselves significantly, after a few generations, of their slave ancestors. In September 1743, however, they were prevented from exercising these liberal arts because "the judge Chancellor of that Relation had reduced the number of solicitors" to twenty-eight individuals, excluding both Mendes de Vasconcelos, as they wrote, "on the grounds of being Brown, with great prejudice of the supplicants in the charges they lose, of which they lived". The free Afro-descendants in question, both referring to themselves as "lawyers", requested from Dom João $V$ to have the "mercy of passing provision in order to allow them to pass in all courts of that city to find the causes they have committed nevertheless being Brown, for not being the said attribute an impediment to such an exercise, and much less it should be in Brazil".20

The Mendes de Vasconcelos, moreover, were not the only ones who suffered this type of ban in Portuguese America, ${ }_{1}{ }^{11}$ which incurred as much for them as to the historians, as formulate Elias and Scotson, in a clear "ideological Act of avoidance".22 The case in question, as the of other Afrodescendants curtailed or denied to exercise the Liberal Arts in slave social representations of Bahia and Pernambuco, shows, at first, the marginal aspects - what some historians call "racism", "proto-racism" or "racial relations" - and hides its central nexus, that is, the power relations and the reservation of specific social functions to social groups of the highest level of those social representations. Under this perspective, we are not talking about "racial or class relations" but, more specifically, and more generally, of an established-outsiders relation marked by an enormous differential of power retention. Furthermore, these bans point to the fact that Freed- 
23

BERBEL, M. R.; MARQUESE, R. A ausência de raça: escravidão, cidadania e ideologia próescravista nas Cortes de Lisboa e na Assembleia Constituinte do Rio de Janeiro (1821-1824). In: CHAVES, C. M. das G.; SILVEIRA Marco A. (orgs.). Território, conflito e identidade, Belo Horizonte/ Brasília: Argumentum/CAPES, 2007, pp. 63-88; BERBEL, M., MARQUESE, R. \&t PARRON, Tâmis. Escravidão e política. Brasil e Cuba, 1790-1850. São Paulo: Hucitec/FAPESP, 2010, pp. 180-181.

24

MATTOS, H. M. A escravidão moderna nos quadros do Império português: o Antigo Regime em perspectiva atlântica. In: FRAGOSO, J, et. al. (orgs.). 0 antigo regime nos trópicos. A dinâmica imperial portuguesa (Séculos XVI-XVIII). Rio de Janeiro: Civilização Brasileira, 2001, pp. 148-149 LARA, S. H. Fragmentos setecentistas. Escravidão, cultura e poder na América portuguesa. São Paulo: Cia. das Letras, 2007, p. 282-285.

25

Raminelli, Ronald. Impedimentos da cor..., 0p. Cit., pp. 717-723.
26

SILVA, Luiz Geraldo; SOUZA, Fernando Prestes. Op. Cit., pp. 11-12; SILVA, Luiz Geraldo. Negros de Cartagena y Pernambuco..., Op. Cit., pp. 225227. I have been developing this analysis model from its original formulation proposed by ELIAS, Norbert. Introdução à sociologia..., Op. Cit., pp. 67-75, 93-99; ELIAS, Norbert. A sociedade de corte. Investigação sobre a sociologia da realeza e da aristocracia de corte. Rio de Janeiro: Jorge Zahar Editor, 2001, pp. 267-273. men and their descendants, and not only in slavery social representations of Portuguese America, but also of the French Caribbean and Hispanic America, as I will demonstrate later, while advancing in the process of changing status, were prevented by non-qualifications that continued for several generations, or inter-generationally.

Even within the democratic and representative type society such impediments were kept, since slavery followed its course in many of the specific social representations once linked to the comprehensive social figurations of the Colonial Empires. According to the political Constitution of the Empire of Brazil of 1824 - considered by some historians as "highly inclusive" ${ }^{23}$ - the Freedmen were second-class citizens, since, as they pray, they had only passive citizenship, which allowed them only the enjoyment of civil rights, but not of political rights. As I will also demonstrate later, many free Afro-descendants of Imperial Brazil expressed openly their revulsion to this constitutionally established impediment in a democratic and representative type society. They did certainly not share with the point of view of historians who regard that legal text as "highly inclusive".

However, the most important to emphasize is that in all slavery formations, ancient and modern, the political-legal status of free man is not the end of the process of marginalization, but the end of a previous phase, which is slavery, it is having different stages. Thus, the nature of the sociological stigma assigned to the freedman in slavery societies of the New World was not a result of "racial or proto-racial ideology", as some analysis propose ${ }_{1}^{24}$ but of its ancestor and procedural link with the slave status. Thus, in modern slavery societies, in which social slavery relations between groups of different "colors" or "races" predominate, the "color deffect" consisted only in the form in which the socio-dynamics of the stigma against the former slave, or their descendants, assumed a visible face. In addition, to the contemporary the impediments imposed on individuals of that social group were based not on an "anachronistic racism" appropriately criticized by Ronald Raminelli, but on the "mechanical defect" associated with the exercise of dishonorable or vile trades and professions mainly executed in an intra-generational or ancestor captivity. ${ }^{25}$ At the same time, analytically speaking, the sociological basis of those impediments rested ultimately, as Elias and Scotson propose for a huge variety of cases in time and space, in the structure of power relations between established-outsiders, that is, in the social tensions marked by the monopolization of prestigious social functions by individuals of the highest social level.

III

The social positions of free and freed Afro-descendants must also be understood synchronously within the transition process between the old or oligarchic type society to another, democratic and representative type, which will become prevalent throughout the 19th Century. I have already presented this theoretical model in other articles. ${ }^{26}$ I retake it here to complement the diachronic questions treated before around the slaveryfreedom continuum. Furthermore, these diachronic and synchronic plans are not optional, but interdependent: while the first allows to connect the theme in question with many other established-outsider relations or other slavery representations in several contexts in time and space, the other shows specific social representations and their particular dynamics of social development. 
On the concept of honour and birth, due to the perception of individuals of the highest level in old type society, see MARAVALL, José Antonio. Poder, honor y elites en el siglo XVII. Madrid: Siglo XXI, 1989, pp. 11-145.

28

About the cabildos de nación in Cuba, but with a very different interpretation of the one I make about this type of institution, see CHILDS, Matt D. The 1812 Aponte Rebellion in Cuba and the Struggle against Atlantic Slavery. Chapel Hill: The University of North Carolina Press, 2006, pp. 78-119; about the cabildos de nación in New Granada, see the excellent article of HELG, Aline. The limits of equality: Free people of colour and slaves during the first independence of Cartagena, Colombia, 1810-1815. Slavery \&t Abolition, vol. 20, n. 2 1999, p. 13; about the candombes of Buenos Aires, see article of CHAMOSA, Oscar. "To honor the ashes of their forebears": the rise and crisis of African Nations in the Post-Independence State of Buenos Aires, 1820-1860. The Americas, vol. 59, n. 3, 2003, pp. 347-378. A good article about the "Afro-portenha" population is from CANDIOTI, Magdalena. Altaneros y libertinos. Transformaciones de la condición juridica de los afroporteños en la Buenos Aires revolucionaria. Desarrollo Económico, vol. 50, n. 198, 2010, pp. 271-296. About the relations between power and fraternities in Portuguese America, see my article SILVA, Luiz Geraldo. Religião e identidade étnica. Africanos, crioulos e irmandades na América portuguesa. Cahiers des Amériques Latines, vol. 44, n. 3, 2003, pp. 77-96.

29

This type of perspective is also present in other interpretations of the old type society. See, for example, GUEDES, Roberto. Ofícios mecânicos e mobilidade social..., Op. Cit., pp. 398-412.

30

LARA, Silvia H., Palmares \& Cucaú: 0 aprendizado da dominação. (Thesis presented for the selecting process for Professor at the Area of History of the Brazil). Instituto de Filosofia e Ciências Humanas da UNICAMP, Campinas, 2008, pp. 174-195.

31

RAMINELLI, Ronald J. Nobreza e riqueza no Antigo Regime Ibérico setecentista. Revista de Historia. Vol. 169, n. 2, 2013, pp. 83-110.

32

ELIAS, Norbert. Introdução à sociologia..., $0 p$. Cit., pp. 80-81.
Were it in Europe, were it in America, the old or oligarchic type society, deeply hierarchical and ordered, was characterized by the existence of two different social levels. The first level, higher and more reduced, was formed in America by Europeans and their descendants, which performed, sometimes simultaneously, tasks associated with the royal-social types of big landowners and large merchants, and/or social functions linked to military, bureaucratic-State or clerical life. The foundation of their social distinction, according to their representation of the society in which they lived, came from the self-attribution of value to their own notions of honor and birth. ${ }^{27}$ On the other hand, the lowest level, more expanded, was established in American slave societies mostly by free and freed Afrodescendants, were these Africans or Creoles, who performed professions connected to craft, or acted as small farmers or small traders. In addition, individuals of the lowest level performed social functions such as militia officers of military regiments sponsored by the Spanish, Portuguese or French Catholic Monarchies, and performed central political functions to their social level as brothers of fraternities and sororities, or as members of cabildos de nación or candombes. ${ }^{28}$ African and Creole slaves, in their multiple and differentiated statuses, were also at the lowest level and occupied the worst social positions and statuses, since in many cases they established in free and freed Afro-descendant properties.

There was an unstable balance of power between these levels, as well as an unstable balance of power within each of them. Thus, individuals and social groups of the highest level had their own tension fields, as well as their hierarchies, whereas the same happened at the lowest level. The social ascension in an old type society was restricted, therefore, to each one of these levels. ${ }^{29}$ Individuals in the lowest level never reached across to the upper level. They ascended only within the existing hierarchy in their own level, which was distinct from the highest level, moreover, as a result of dishonor, common to all their members, from the current or ancestor, intra or inter-generational slave status. These levels, as I have already observed, kept an unstable balance of specific power during the old regime because they were interdependent and communicated with each other. Evidently they were not the same, as is suggested, to my view inappropriately, in some historiography works about "slave resistance" ${ }^{30}$, because there was a huge differential in power retention between them. The highest level evidently concentrated a lot more power than the lowest level. It can be affirmed that in the old or oligarchic type social figurations, the potential of power retention that favored the highest level was disproportionate, rigid and stable. Were it in Europe, were it in America, individuals and groups of the highest level of the old type society, whose reproduction, besides being based on modern criteria of wealth, ${ }^{31}$ was especially placed in the older criteria, ingrained and valued of honor and birth, were sure that their social position was immutable and unquestionable. However, the lowest level also had power, since it is not an object, a thing, but a social relation..$^{32}$ In this way, the lowest level imposed limits to the actions judged as unlimited or "absolute" by individuals and groups of the highest level.

As I suggested earlier, free and freed Afro-descendants can, in a transitional phase, assign value and meaning to their lives both coming from old or oligarchic type society, as from the new figuration of democratic and representative type in process of constitution, which engenders 
new relations of power, as well as a new unstable or pendulum balance between the highest and lowest social levels. In this new structure the relation between the two levels of society changes, as there is more proximity between them and less concentrated power retention potential at the highest level. The new unstable balance of power between the highest and lowest levels becomes more flexible, more elastic, and much more complex, since the pressure applied since the lower level becomes more continuous, stable and conscious. In this new stage, the unprecedented and growing demands for equality and for civil and political rights by groups and individuals of the lowest level, observed in all colonial empires of modern era along the transition phase processed between the last quarter of the 18th Century and the first decades of the following Century, led to the decrease in distance between those levels.

At the same time, the pressures applied since the lowest level intertwine with tensions and ruptures triggered at the highest level, whose balance of power weakens as a result of the crisis of sovereignty expressed in both comprehensive social figurations, such as the colonial empires, as in specific social representations, such as the so-called "colonies" and "metropolis". And thanks to the reduction of the differential of power retention of the highest level, the struggles and tensions between the two levels become more open and more straightforward, since they are based on modern concepts such as political equality and citizenship, and not on old notions of honor and birth. The distances between levels decrease, which opens the possibility of creating a more horizontal and more representative structure of social relations, with individuals from the highest level speaking on behalf of the lowest level social groups, and individuals of the lowest level, having at least legal and political conditions to ascend to social functions of representation. In later stages of the democratic and representative type society, notably in the multiparty, in particular, appears at the same time, the possibility of creating several intermediate social levels, some closer to the highest level and others closer to the lowest level, all with their own pendulum balance of power. ${ }^{33}$

One may not forget, finally, that this model must include an emotional dimension, related to feelings produced mutually in the social structures of personality of individuals from both levels. Considering only the legal and political conditions, that is, the "merit, talent and virtues" of isolated individuals, is equivalent to forgetting the social representation formed by social groups of the highest and lowest levels, and the social stigmas that they use in their struggles against each other. So, in the old or oligarchic type society, while social groups of the highest level see their higher power as a sign of higher human value, social groups of the lowest level, due to the large potential of concentrated power retention of the highest level, agree and incorporate forms of current power relations and reveal a inescapable submission to the order - whose most palpable incarnation are the own Spanish, French and Portuguese Catholic Monarchies - experiencing "affectively their inferiority of power as a sign of human inferiority".34

Overcoming this emotional dimension in the democratic and representative type society presents, for the most part, significant obstacles, despite the decrease in the potential of power retention by groups and individuals of the highest level and the political-legal institutionalization of political equality between free men. This is because, on the one hand, the emotional barriers erected by feelings of superior virtue of individu- 
O Brasileiro Pardo, n. 1, Rio de Janeiro, 21 October 1833.

36

Carta régia proibindo a existência de corpos separados de pardos e bastardos. Documentos Interessantes para a História e Costumes de São Paulo. Vol. XXIV, s/d, p. 43-44.

37

Letter from the Governor of the Captaincy of Pernambuco, Duarte Sodré Pereira Tibão, to King D. João $V$, stating there is no need for separate bodies of Browns and blacks, suggesting the extinction of master stations and field sergeant major of the same, as well as the Governor of the Indians. AHU-PE, box 42, doc. 3797. Recife, 10 March 1732

38

CONSTITUIÇÕES Primeiras do Arcebispado da Bahia. São Paulo: Tipografia 2 de Dezembro de Antônio Louzada Nunes, 1853, p. 93.

39

RAMINELLI, Ronald. Impedimentos da cor..., Op. Cit., p. 721 als of the highest level and, on the other hand, the sense of lower human value of group dishonor, incorporated in the self of the individuals of the lowest level, do not follow the same rhythm of the increasing limitation of the political-legal disqualification which characterized the social position of the last in the previous phase. Moreover, since within the democratic and representative type society the social tension field is more open and more horizontal, power relations and disputes for prestigious social functions, apparently processed in an impersonal and detached way as a result of existing legal landmarks, can be punctuated by eventual recurrences to "signs of strengthening" - as references to the color of the skin or the ways of speaking and behaving publicly. Hereby, they seek to weaken opponents from the old social outsider group referring to this emotional dimension of social tensions. This argument can be illustrated by means of a newspaper from October 1833, in which they accused Evaristo da Veiga of describing, in the context of political-party tensions, free and freed Afro-descendants as "slipper Patriots", "men of knife up their sleeve" and "people of stick and dagger". ${ }^{35}$ Inversely, the open complaint of the recurrence for signs of strengthening, as I will demonstrate later, was classified as unpatriotic and divisive, as can be seen in the tension field born in the representative republics of Hispanic America and the French Caribbean, as well as in Imperial Brazil.

\section{IV}

The examples available in the Portuguese and Spanish Empires with respect to the use of "signs of strengthening" - such as skin color, for example - to disqualify applicants to prestigious social functions linked inter or intra-generationally to captivity are many and varied. In January 1731 , for example, King Dom João V took measure, a few years later reversed, to extinguish the militias in the whole State of Brazil formed and controlled by free and freed Afro-descendants. ${ }^{36}$ In a letter of March 1732, the Governor of the Captaincy of Pernambuco, Duarte Sodré Pereira Tibão not only agreed with such measure, but also sentenced that he did not tolerate the "Black regiment here, considering it outrageous that a black without more merit than that of a mechanical job, received a patent of Camp-Master, and another of Sergeant-major".37

This view was part of a more general doctrine. According to the "impediments, and questionings" to candidates for ecclesiastical functions in the "Minor Orders, as Sacred" contained in the First Constitutions of the Archbishopric of Bahia, of 1707, were excluded from the exercise of those functions the ones that "are part of Hebrew, or of any other infected nation; or black or Mulatto". ${ }^{38}$ In turn, the judge of the City of Porto and familiar of the Holy Office, Diogo Guerreiro Camacho Alboym, observed in his book Escola moral, política cristã, e jurídica, published in 1759, that the "mulattos", particularly "come from a mixture of free blood and captive blood, resulting in such a pernicious mixture". As a result, says Alboym, these would be naturally "inclined to evil, lacking faith, contumacious, rebels, given to vices, incorrigible; reason why they are rightly excluded from public offices".39

However, it is not less remarkable that feelings of superior virtue, values and social meanings attributed to themselves by individuals and social groups of the highest level can be incorporated by individuals and social groups of the lowest level when they face each other in tensions 
40

Notification of the Secretary of State of the Navy and Overseas, Tomé Joaquim da Costa Corte Real, to the President of the Overseas Council, Marquis of Penalva D. Estevão de Meneses ordering to see the request of captains and more officers from the third of Henriques of the garrison of Bahia to only name the national Creoles to officers of the named Third in the same way as is practiced in Pernambuco, where the third was created. AHU-BA, cx. 137 doc.77. Belém, December 3, 1756. and disputes for prestigious social functions, since, as I already argued, the lowest level also had, as the highest, its own unstable balance of power. In January 1745, for example, seven captains "of the third of Henriques of the garrison of the town square of Bahia" signed a petition on behalf of all the officers of that militia consisting of free and freed Afro-descendants in which they emphasized the "inviolable, and the right style of not being provided from fleet Corporal up to the rank of Captain any man who was not a natural from the land, as are all the Creole officers that compose the third of Pernambuco".

However, say the captains, "that style changes and adulterates in the third of Bahia, in notorious discomfort of the Republic and the Royal service of Your Majesty". The indignation of the "Creole" captains, that is, born in America, referred to the fact that the Captaincy of Bahia authorities were providing "in those positions men of different nation, such as those from the Costa da Mina, infected people, lacking faith to God and your Majesty". The socio-dynamics of the ongoing stigmatization perpetrated by "creoles" called for the widespread sense of superiority among individuals of the highest level, while accusing Africans from Costa da Mina to be closer to the slaves in the freedom-slavery continuum than to their specific social position.

According to the "creoles", Africans were "largely capital enemies of the white, against whom each day fulminate insurgencies and they can easily, with exercise of weapons, do some rising in people, accompanied by black captives and fugitives". The concern of the "creole" captains was to avoid "harmful errors and consequently a great note in the Regiment of Supplicants who with zeal and faithfulness serve Your Majesty".40 The antagonists, in this case, were all black, not having, therefore, any "racial" differences between them. Their social positions from the point of view of slavery were relatively similar, since all were free or freed, although, of course, the "Creoles" were in a more advanced stage of the process of change of status than Africans, or closer to freedom than to slavery.

But, for this analysis, as I already emphasized, these signs of strengthening, these "identities", matter less and matter more the structure of social tensions then prevailing, that is, the unstable balance of power on the lowest level, and the specific forms of stigmatization that mediated the disputes around the monopoly of prestigious social functions. They replicated in the mobile balance of tensions in the lowest level the same pattern processed in the unstable balance of power that existed between this and the highest level, including using the same stigmatizing epithets, such as "infected people".

In the Spanish Empire the examples of "signs of strengthening" used by individuals and social groups of the highest level in the context of disputes for prestigious social functions involving social groups of the lowest level are particularly evident in the Viceroyalty of New Granada. In this specific social figuration free and freed Afro-descendants were relatively majoritarian to the other social groups, and their elites saw in the d'El Rey militias ways to get signs of social distinction then reputed as vital in internal struggles for power in their social level.

In August 1767, for example, brown and dark militiamen of Caracas, in the Captaincy General of Venezuela, affirmed providing services to the monarchy of Castela on the "costas de dicha provincia, evitando los insultos, y hostilidades, con que los corsarios, y piratas enemigos la infestaban", 
Las milicias de Pardos de Caracas solicitan se las provea de vestuario, se las conceda el título de Regimiento y poder comercializar dos mil fanegas de cacao. Archivo General de Simancas (Doravante A.G.S.), Secretaria del Despacho de Guerra, SGU, Leg. 7198, 7, hojas 40-44. Caracas, 17 August 1767.

MCALISTER, L. N. The "fuero militar" in New Spain. Gainesville: University of Florida Press, 1957, p. 43-54

43

LASSO, Marixa. Myths of harmony. Race and republicanism during the Age of Revolution, Colombia, 1795-1831. Pittsburgh: University Of Pittsburgh Press, 2007, pp. 20-33.

44

MIERS, Suzanne; KOPYTOFF, Igor. Op. Cit., pp. $19-20$ as well as "aprisionando los esclavos de ellas, entregando al fuego las chozas, en que estaban abroquelados". In these services they were "expuestos a perder vidas, y sufriendo constantemente las inclemencias del tiempo, y las necesidades, que son anexas a dichas fatigas".

They requested, therefore, that se les conceda el renombre, y confirmación de Regimiento con la advocación, y patrocinio de Jesus, María, y Joseph; declarándoles leales Pardos de Caracas", while "permitiéndose a los capitanes que traigan colgado al pecho el escudo de las Armas Reales; y a todos los oficiales, y soldados traer de día, y de noche en traje acostumbrado espadas de Marca".41 In turn, under the bourbon reformist policies, free and freed Afro-descendants of New Granada saw ways to penetrate social functions until then monopolised by individuals and social groups of the highest level. Tension fields were created around two key points: the military court extended to disciplined brown and dark militias from the mid-18th Century on, ${ }^{42}$ and the cédulas de gracias al sacar, regulated by Royal Decree of 10 February $1795 .{ }^{43}$ These, particularly, allowed marked free and freed Afro-descendants, in the terms of Miers and Kopytoff, by worldly achievement and success ${ }^{44}$ to buy exemptions of the quality of Browns and quarterones in order to remove impediments to enter institutions that constituted antechamber to prestigious social functions - such as universities, seminaries and convents.

In relation to the military court, the representation submitted by ordinary mayors of the city of Caracas, in the Captaincy General of Venezuela, to King Carlos III on 28 June 1762 is exemplar. According to its terms, "habiéndose declarado a los oficiales, cabos, y toda la demás gente de las compañías de mulatos de esta ciudad el fuero militar" some militiamen had concluded "que este en todos casos los exime de la jurisdicción que ejercemos los alcaldes ordinarios de ella con cuyo oficio así por la obligación, que nos asiste de conservarla en la integridade". Both the sociodynamics of stigma as the disputes for prestigious social functions there processed refer to connection plans, to structural regularities and recurrences that marked the social position of free and freed Afro-descendants in all colonial empires of the modern era. On the one hand, according to the individuals of the highest level invested with functions of superior members of the cabildo, "tanto adelanta esta gente sus pensamientos, y aun quizá se cree, o pretende ennoblecer por los grados, y confundirse con la gente noble sin embargo su bajo color, de la esclavitud de su inmediata, a cercana ascendencia de mulatos, y negros". At the same time, the members of the cabildo of Caracas emphasized that individuals of this social group "exercen todos los oficios serviles y mechanicos hasta los de carniceros y pulperos" and thus, thanks to the military court they enjoyed, "se está experimentando el que a la sombra de dicho fuero se desordenan de modo que en ningun oficio se experimenta puntualidad". Apart from the signs of strengthening connected to the skin color of free and freed Afrodescendants, considered here as secondary and marginal, they included also their conduct in the lexicon of stigmatization. Thus, still according to the mayors, "algunos de ellos para distinguirse más, y confundirse en algún modo con las personas blancas, y nobles sean llegado a poner pelucas", trend quickly suppressed by the Governor of the Captaincy. However, it seemed even more absurd to the members of the cabildo that the "pobres sastres mulatos" had expressed "tan públicamente su desazón de que el capitán general no les aprobase el llevar pelucas", symbol that was far 
Quejas de los alcaldes ordinarios de Caracas por la concesión del Fuero Militar a las Milicias de Pardos de Caracas. A.G.S., Fondo Secretaria del Despacho de Guerra, 1762-1765, Leg. 7198,3, pp. 15-24. Caracas, 28 June 1762
Expediente sobre la admisión de los hijos de Diego Mejias Bejarano a la Universidad. 18011805. Archivo General de Indias, Audiencia de Caracas, legajo 976. Apud: HISTORIA de las ideas pedagógicas en la Venezuela colonia (1767-1821). Fuentes primarias para su estudio modulo aprendizaje. Caracas: s/e, s/d, pp. 1-16. from seeming ridiculous in the old or oligarchic type society. After all, conclude the ordinary mayors, it did not seem correct to proceed in "concurrencia a una cosa tan circunstanciada del Real servicio".45

In turn, the free Afro-descendant Diego Mexias Bejarano, native of the city of Caracas, received from Carlos IV in July 1796 and September 1797 two royal ballots on which he was dispensed "para todos los efectos civiles su política calidad de pardo". In October 1801, moreover, another ballot rectified that "favor", and extended it to his children, "habilitándoles por el mismo hecho, y por las claras terminantes expresiones con que se halla concebido el Real despacho para entrar en Religión, vestir hábitos clericales y ascender al sacerdócio". The intention of that free Afro-descendant endowed with the worldly achievement and success was that Lorenzo Mexías Landaeta "uno de los naturales y legítimos hijos, fuese admitido al curso de Artes que debía abrirse en los generales de la Real y Pontificia Universidad de esta ciudad". However, on the one hand, if, in the context of the slavery-freedom continuum, worldly achievement and success, as Miers and Kopytoff formulate, reduces the marginality of everyday existence and indicates success in business or in life, it seems unnecessary to say, on the other hand, that it can occur with or without any change in both the political-legal status, as well as in the status of affective incorporation, or the prestige ranking. Indeed, the Rector of the Universidad de Caracas, Nicolas de Osío, prevented the entry of Lorenzo in the cloister under the argument that the "primeros negros que pasaron a la América han llegado a nuestros puertos marcados con toda la ignominia de la barbarie y con toda la infamia de la esclavitud". These "victimas de la ferocidad de sus cohermanos que los privaron de su libertad" were, in general, still according to the Rector, "hombres inclinados al robo, sanguinarios, suicidas, cubiertos por lo común de la confusión de las costumbres más bárbaras" Precisely these were, anyway, "los ascendientes que forman el principal tronco de la genealogía de los pardos". Osío spoke on behalf of individuals of the highest level social groups, that is, the "vecinos blancos de todas clases, europeos y criollos, la nobleza y el pueblo que tienen a la vista el origen bajo y despreciable de los pardos" this "raza media entre blancos y negros" whose origins, beyond captivity, were founded "na continuada serie de generaciones prohibidas, de comercios torpes y de uniones proscritas por todas las leyes". It was no use to Diego Mexías to request Carlos IV to treat his sons "como a los demás escolares, sin agraviarlos ni ofenderlos por la accidental diferencia de su color" ${ }^{46}$ referring to the sign of strengthening that distinguished him from individuals of the highest level. In a social figuration formed by a vast majority of free Afro-descendants including some who were endowed with worldly achievement and success, the attribution of stigma and the impediment to the prestigious social functions seemed fundamental conditions to maintain the cohesion of social groups of the highest level. It was therefore to transform the immense potential of power retention obtained by these in a sign of higher human value and to disseminate among the outsiders, affectively speaking, the idea according to which their inferiority of power was a sign of human inferiority.

\section{$\mathrm{V}$}

Still in the context of the old or oligarchic type society, or especially in the acute phase of the illustrated reforms undertaken from the mid-18th Century on, individuals of the elites of social groups consisting of free 
47

BERBEL, M., MARQUESE, R. \& PARRON, T. Op. Cit., chap. 1.

48

ELIAS, Norbert. Sobre o tempo. Rio de Janeiro: Jorge Zahar, 1998.

49

DUNNING, Eric \& HUGHES, Jason. Op. Cit., p. 50; for a criticism to the notion of "system", see ELIAS, Norbert. 0 processo civilizador (vol. 1). Rio de Janeiro: Jorge Zahar Editor, 1994, pp. 232-233. 50 BERBEL, M., MARQUESE, R. \& PARRON, T. Op. Cit., p. 20.

51

ELIAS, Norbert. Introdução à sociologia..., $0 p$. Cit., pp. 68-69. and freed Afro-descendants from Portuguese America and the French Caribbean sent representations to overseas authorities in Lisbon and Paris requesting privileges, forums and franchises that allowed them to occupy prestigious social functions in their respective specific representations. Such social functions, according to those representations, were forbidden to them as a result of "their color", closely associated, as we saw in the previous examples, to their ancestral link with captivity. Despite the deep differences between the social slavery representations of the Portuguese and French Empires, the demands produced by free and freed Afro-descendants of those colonial empires refer clearly to recurrences, connection plans and structural regularities, including cross-references, as a result of the common social position they held in the freedom-slavery continuum.

However, contradicting this assertion, a recent study suggested the impossibility of seeing such demands from a perspective that highlights the structural regularities and recurrences that connect actions and representations of free and freed Afro-descendants of those social representations. In counterpoint to what I advocate here, the analysis model in question postulated the existence of two distinct "Atlantic systems": on the one hand, the "Iberian", which gathered the Portuguese and Spanish Empires, and, on the other hand, the "Northwestern European", which encapsulated the Dutch, French and British Empires. According to this analysis model, such "systems" should be seen as relatively independent phenomena, since their genesis and development processes were enclosed in different successive "historic structures.".7 Still according to the same study, the essential difference between these "historic structures" stems mainly from the fact that both "systems" have been formed in "different or discontinuous times" - as if the "time", by the way, was a physical or metaphysical entity, and not mere future represented progressively by increasingly higher synthesis levels, as a result of the social development of the entanglement chains between human beings. ${ }^{48}$ In turn, notions such as "historic structures" and "system" seem to suggest that societies hover above individuals, ruling them or constituting independent entities of them, as if it were not the human beings, as Dunning and Hughes formulate, that as they act, think, hold positions of status and perform specific functions, formed "structures". 49

The closed and static notions of "Atlantic systems" closed in distinct "historic and temporal structures" produce at least two undesirable and inadequate results. The first refers to the fact that by emphasizing the "uniqueness"50 of such "systems", conceiving them as relatively isolated and closed units, at last, as "systems", this analysis model prevents us from seeing how certain actions and representations taken by free and freed Afro-descendants within social slavery figurations of Portuguese and French Empires can be examined through connection plans, recurrences and structural regularities that effectively and analytically linked their individual processes of social development. This would make it possible to observe a "structural parallelism" both in those actions and representations as in the development of a group of those societies, thereby facilitating the study of "global social changes". ${ }^{51}$ However, the perception of these parallels is prevented when we remain in the specific spheres of social development. Thus, when proposing connection plans between the representations of human beings who constituted the colonial empires of the Atlantic world, including the British and Dutch Empires, the analysis model here in question suggests that the only entities that effectively articulated them 
BERBEL, M., MARQUESE, R. \& PARRON, T. Op. Cit., p. 75; see also TOMICH, Dale. Atlantic History and World Economy: concepts and constructions. Proto Sociology, vol. 20, 2004, pp. 102-121, according to which the "capitalist world economy" would be the prime locus from which everything is born and in which everything ends. In this sense, this seems to perfectly embody the belief of holism, according to which "the whole is greater than the sum of its parts".

53

BERBEL, M., MARQUESE, R. \& PARRON, T. Op. Cit., pp. 38-39, 85.

54

Ibidem, p. 65. were "the game of international politics" processed among individuals and social groups of the highest level and the "capitalist world-economy" - a vague entity relating to a single sphere of social development and that, after all, refers to explanatory marks of unequivocal holistic character..$^{52}$

The second unwanted and inappropriate result of the analysis model here in question stems from the fact that by emphasizing the isolated character of the "Atlantic systems", the study here in consideration tends to reiterate old cultural theses. According to its terms, prevailed in the specific social representations of the "Northwestern European Atlantic system", on the one hand, a fierce and inflexible "racial politics", accelerated in the case of the French Empire after the Seven Years War (17561762). On the other hand, in those representations existing on the opposite pole, that is, in the "Iberian Atlantic system", particularly in Portuguese America, there was constituted a "complex multi-ethnic society", marked by the "segregated incorporation", it is true, of free and freed Afro-descendants, but in which the "concrete social practice" operated "almost always in the way of inclusion".53 This result, which highlights even more the irreconcilable opposition between those "systems" was produced solely by another isolated sphere of social development: "culture". While in the "Iberian system" prevailed the "ideological program of the Second Scholasticism", its counterpart of the "European Northwest" was beset by the "idea of freedom" and by the "Atlantic republicanism originated in the seventeenth Century revolutions". ${ }^{44}$ Thus, the various "systems" connected by the holistic "capitalist world economy" and holding separate "cultural" spheres, produced different types of societies, which, in turn, gave different social destinations to the free and freed Afro-descendants. On the one hand, those societies linked to the "Northwestern European system" tended to the "rationalization of social relations", while they, paradoxically, engendered abolitionism, whereas the societies belonging to the "Iberian system" perpetuated slavery, but also paradoxically became "multiethnic" and tended to social "inclusion". The thesis of the "two singular historic structures", of the "two times", which is the result of a recovery, accompanied by proper criticism, of the thesis of Frank Tannenbaum and Eric Williams, passing through the central inflection to the analysis model here in question, present in the work of Sidney Mintz, ends up, for the topic that interests us here more directly, converting after all in a genuine neofreyrean bias of interpretation.

I conclude, therefore, that one of the central problems of that analysis model is to disregard the content of great empirical material produced by free and freed Afro-descendants of the comprehensive social representations of the Spanish, Portuguese and French colonial Empires, aspect which does not allow to see the connection plans, recurrences and the structural regularities that it evokes. The numerous petitions and demands elaborated by those individuals, in addition to revealing the high degree of cohesion of their social group, made it clear that whether it was in the Spanish, Portuguese or French Empire, restrictions were imposed on them throughout the process of status change entered in the freedom-slavery continuum. Apart from the restrictive written rules, the social practice of those representations indicate the fact that the closer of liberty and the more they ascended in the ranking of prestige, and the more successful they were in their worldly achievement and success, free and freed Afrodescendants and their descendants could run into impediments arising 
As suggested by Raminelli about the Portuguese Empire, but from another focus, "mulattos threatened the social hierarchy in a more incisive form than blacks did. In fact, the term mulatto race arose in the habilitation process when the descendants of captives pleaded social positions disputed between the pure white Catholics. "RAMINELLI, Ronald. Impedimentos da cor..., Op. Cit., p. 722.

56

VOELZ, Peter M. Slave and soldier. The military impact of Blacks in the colonial Americas. New York: Garland Publishing, 1993, pp. 3-9.

57

RUSSELL-W00D, A. J. R. Escravos e libertos..., Op. Cit., pp. 107-142; RUSSELL-WOOD, A. J. R. Ambivalent Authorities: The African and Afro-Brazilian contribution to local governance in Colonial Brazil. The Americas, vol. 57, n. 1, 2000, pp. 13-36; SCAMMELL, G. V. Indigenous assistance in the establishment of Portuguese power in Asia in the sixteenth Century. Modern Asian Studies, vol. 14, n. 1, 1980, pp. 1-11; RODRIGUES, Eugénia. Cipaios da Índia ou soldados da terra? Dilemas da naturalização do exército português em Moçambique no século XVIII. História Questões e Debates, vol. 45, n. 2 2006, pp. 57-95; CANDIDO, Mariana P. South Atlantic Exchanges: The Role of Brazilian-Born Agents in Benguela, 1650-1850. Luso-Brazilian Review, vol. 50, n. 1, 2013, pp. 53-82.

Blackburn, Robin. A construção do escravismo no Novo Mundo. Do barroco ao moderno (14921800). Rio de Janeiro: Record, 2003, pp. 351-353. from their specific social position, generally manifested in terms of "race".55 In fact, all the slavery societies of the Atlantic world were "racists" or, as it is preferable to formulate, in all of them the social and power relations and the competition for prestigious social positions were punctuated by recurrences to signs of strengthening regarding skin color. Thus, what changes are not the "racial relations", the "culture" or the use of signs of strengthening whose systematic manifestation we call "racism", but the specific form through which social and power relations were processed involving individuals and social groups of the highest level and the lowest level, as a result of the particular social representation they formed.

Going beyond, I postulate that, aside from recurrences, the connection plans and the structural regularities which I have sought to highlight, the changes that occurred from a colonial Empire to another refer therefore to the degree of need that each of their specific social representations have to make use of these signs of strengthening in the context of their relations of power and of the dispute for prestigious social positions. All colonial Empires of the modern era were deeply dependent on their free and freed Afro-descendants, as stressed Peter Voelz, ${ }_{1}^{56}$ but the Portuguese Empire, according to a copious number of analyses, was, among them, the most dependent on recruited individuals in Asia, Africa and America to perform a number of tasks and social functions that also predicted possible displacement between their various parts. ${ }^{57}$ This, however, does not mean that there was a creation of a "complex multi-ethnic society" here marked by social "inclusion". Before, the specific form in which the interweaving among human beings were woven, as well as their relations of interdependence, just showed a less ostentatious use, if compared to other colonial Empires, of these signs of strengthening, which does not mean that they did not exist or that they were left aside by individuals and social groups of the highest level. At certain moments and in specific Portuguese American representations, the recurrence to the signs of strengthening tended to be as intense or more as in any other slave society of the comprehensive social configuration of the Atlantic world. Or at least this is what the many voices from the past alert us through numerous petitions.

\section{$\mathrm{VI}$}

Between 1785 and 1786 the free Afro-descendant Julien Raymond submitted four memoranda to the Overseas Minister requesting urgency in reforming the legislation about "racial discrimination" in Saint-Domingue. Containing several references to ancient and modern writers, the memoranda highlighted recurring topics in the writing of free and freed Afro-descendants of the Atlantic world, such as the economic productivity of their social group, their usefulness to the State and the moral respectability that characterized the members of their elite. Furthermore, the documents requested, among other aspects, the reintroduction in Saint-Domingue of the Code Noir of 1685. This, as we all know, was strict with slaves, but not with freed Afro-descendants, which, according to that regulation, were legally assimilated to the Freemen as soon as they obtained their politicallegal status of freed. ${ }^{58}$ Both in the opening and at the end of the first of those memoranda, Raymond describes himself as an individual committed to restore the "Roman practice" in Saint-Domingue, according to which the descendants of slaves became full citizens after two generations referring, therefore, to a typical problem of slavery as a process of status 
GARRIGUS, John D. Before Haiti..., Op. Cit., p. 7, 217-219, 317.

Consultation with the Overseas Council to the Prince Regent Dom João, about the representation of Brown Men of the Captaincy of Goiás, requesting admission to the service of the Chambers of the Captaincy, in any public job, because they have the necessary qualifications, regardless of their color ... AHUG0, cx. 47, doc. 2700. Lisbon, 7 January 1804; SILVA, Luiz Geraldo. "Esperança de liberdade". Interpretações populares da abolição ilustrada (1773-1774). Revista da História, vol. 144, 2001, pp. 107-150; LIMA, Priscilla. De libertos a habilitados. Interpretações populares dos alvarás antiescravistas na América portuguesa (1761-1810). Dissertation (Master in History). Department of Humanities, UFPR, Curitiba, 2011, pp. 23-30. change. In the same memorandum Raymond presents Brazil and the Spanish colony of Santo Domingo as contemporary societies to his that had prospered by reducing the legal impact of discrimination to the Freedmen. ${ }^{59}$

This, however, did not seem to be the point of view of the free Brazilian Afro-descendants themselves. In February 1803, for example, a vigorous and expressive group of 82 individuals of the Captaincy of Goiás, in the far west of Portuguese America, addressed a long petition to the Prince Regent Dom João, in which they resumed topics used by Raymond 20 years earlier. By auto-representing themselves as "the most useful vassals to the State in this Colony", they said, however, that they were being "treated with contempt, despite the military graduations their Governors had rewarded them, and the intelligence, capacity and good instruction that many of them have for any Job in the Republic". Situating their demands within the illustrated reforms, they reminded the Prince, on the one hand, of "the Providence given in favor of mestizos of India" in 1774, as well as the Act of 1773, which made free and freed Afro-descendants born in Portugal able to all services and to "serve equally with the natives of the Kingdom, without difference". However, they claimed that in the specific representation they were included, that is, the captaincy of Goiás, there was no "compliance with the Laws of Your Highness, who wisely favors and enables all to any employment of the civil society".

After indicating cases of several individuals of that captaincy excluded from prestigious social functions because they were Afro-descendants, they winded up: "It seems that the supplicants should not be treated as awkward for any Job of the Republic, for the benefit of the State, having the ability and intelligence needed to perform them, except for the color defect".60

Although they seem to foreshadow typical requirements of the democratic or representative type society, these demands, even being formulated in the illustration context, had nothing to do with abstract political ideals. Such petitions and memoranda contained very concrete requests and complaints of infringements, and nothing else, and, therefore, situating in the context of demands for privileges, exemptions and typical forums of the old or oligarchic type society. The petition, elaborated in the Captaincy of Goiás, for example, referred to free Afro-descendants excluded of the occupation of the "Office of Notary of the Army Trial", of the "use of Notary of this village" and, more important, the function of "Councilor" of Vila Bela, prestigious social functions that were denied to them as a result of the ancestral link with captivity and, allegedly, of their "color". Far they were, therefore at this stage, from aspiring equality in abstract and conscious political terms.

\section{VII}

Within the comprehensive configuration of the French Empire, the tone rises significantly after the revolution. In January 1791, Julien Raymond published a monograph in Paris entitled Observations sur l'origine et les progrès du préjugé des colons blancs contre les hommes de couleur. His starting point proposed a question: "to know whether the free people of color have the rights of active citizens in the colonies". In these, he observed, "the great white owners, which are the aristocrats, the nobles of the colonies", deny "invaluable rights to the free mulatto, who they hate, and who they need to degrade." To achieve this goal, Raymond continues "they artfully confuse the cause of the people of color with that of the 
61

Observations sur l'origine et les progrès du préjugé des colons blancs contre les hommes de couleur. Par M. Raymond, Homme de couleur de Saint-Domingue. Paris: Belin, 1791.

62

GARRIGUS, John D. Before Haiti..., Op. Cit., pp. 8-12.

63

ROGERS, Dominique. On the road to citizenship..., Op. Cit., p. 76

64

GEGGUS, David P. Haitian revolutionary studies..., Op. Cit., pp. 7, 93-95.

65

GÓMEZ, Alejandro E. ¿Ciudadanos de color? El problema de la ciudadanía de los esclavos y Gente de Color durante las revoluciones francoantillanas, 1788-1804. Anuario de Estudios Bolivarianos, vol. XI, n. 12, 2005, pp. 138-139. slaves; and this confusion tends to embarrass the ideas about the true state of the free people of color". In the monograph, the "true state" of free and freed Afro-descendants from the French Caribbean is presented as a result of the relations between these and "the great white owners" over "three" successive "eras": the first starts in the development years of SaintDomingue, in the late 17th Century; the second refers to the first half of the 18th Century; after the middle of this Century begins the "third age of the colony", period in "which prejudice began".61

The periodization of the "progress of prejudice of white settlers against the men of color" proposed by Raymond, has divided historians. On the one hand, some believe that it corresponds exactly to reality and propose, inappropriately in my view, that it was in the "third era", and especially after the Seven Years War (1756-1762), in which an "explicit biological racism" was produced against free and freed Afro-descendants. ${ }^{62}$ On the other hand, other historians suggest, instead, that the freemen of color were cohesive enough to demand their political rights around 1789 not because their status was deteriorating, "as some analysts have often sustained, but because their high degree of integration had given them new confidence, as well as increased the wealth of their social group as a whole".63 I tend to agree with the latter point of view.

This social group had evident peculiarities in the specific social representation of Saint-Domingue, compared to other social groups of free and freed Afro-descendants, ultimately produced by slavery. They formed an intermediate population group of thirty thousand people squeezed between forty thousand whites and five hundred thousand slaves, which, in general, were represented by a considerable number of individuals endowed with literate culture and worldly achievement and success that had enriched by handmade crafts and mainly by the small agriculture cultivated by slaves. The coffee boom of the decades of 1770 and 1780 had significantly increased their wealth and, as in other American slaveholding representations, they practically dominated the rural police and formed the backbone of the colonial militia, which comprised half of all the squares. Thus, as an egalitarian ideology legitimized, the French Revolution reinforced the social position of free and freed Afro-descendants, providing a political forum until then non-existent within the representation of the comprehensive French Empire. ${ }^{64}$ The practice, now effectively political and conscious, triggered in Paris within the Legislative Assembly by the representatives of the free Afro-descendants of Saint-Domingue, as in the case of Raymond and Vincent Ogé, led to the adoption of the law that guaranteed their active citizenship on 30 April 1792. In this circumstance, Raymond spoke before the Legislative Assembly stating that to the members of that legislature it "was reserved to take a benefactor view to the colonies, to destroy the last and most disastrous of prejudices; it is to the Gentlemen to regenerate the colonies by this truth: the happiness of every society depends on rights equality".65 These events coincided with the end of the monarchy and the beginning of the French Republic, while, under pressure from individuals connected to the French abolitionist movement, slavery was abolished in the comprehensive social representation of the Empire in question in February 1794.

Once the historiography started in the mid-19th Century on the "Haitian revolution" tended to put aside the actions and mental representations of free and freed Afro-descendants and to emphasize the 
Idem, pp. 155-156. About the historiography of the "Haitian Revolution", see GARRIGUS, John D. Before Haiti..., Op. Cit., pp. 13-16.

67

GÓMEZ, Alejandro E. ¿Ciudadanos de color?..., Op. Cit., pp. 156-157.

68

BLACKBURN, Robin. Haiti, Slavery, and the Age of the Democratic Revolution. William and Mary Quarterly, vol. 63, n. 4, 2006, pp. 643-674.
LASSO, Marixa. Myths of harmony..., Op. Cit., pp. 34-67; MÚNERA, Alfonso. El fracaso de la nación. Bogotá: Editorial Planeta Colombiana, 2008, pp. 183-222. slaves "agency", little is noticed that the same movement triggered by the Napoleonic Consulate after 1801, in order to reverse the decree that abolished slavery, also resulted in the reversal of active citizenship to "men of color" from the French Caribbean. ${ }^{66}$ In practice, all free and freed Afrodescendants living in the social representations of Guadeloupe, Martinique and other islands of the Lesser Antilles had their active citizenship reversed between 1801 and the decades of 1830 and 1840. In 1843, for example, when the active citizenship of free and freed Afro-descendants was finally restored, white members of the City Council of Fort Royal, Martinique, not only refused to sit next to Afro-descendant elected members, but also resigned to their posts in droves. ${ }^{67}$ The socio-dynamics of stigmatization continued, therefore, its course in the democratic and representative type societies, and the power differentials between established and outsiders, despite the new status obtained by these, continued to be repeated through what I have called signs of strengthening. The only exception to this tension field produced by established-outsiders relations was experienced in the specific social representation of Saint-Domingue. This, as we all know, after paying a remarkably high cost in human lives of individuals from both the highest level as, and especially, the lowest level, constituted as an independent Republic in January 1804. In the new Republic, named Haiti, all citizens, as states Article 14 of the Constitution of 1805, were formally and legally designated as "Blacks".68 In my view, this equivalence between the sign of strengthening "black" and the modern concept of "citizen" demonstrates, on the one hand, the degree of helplessness of human beings trapped in the peripheral aspect of their relations with groups and individuals of the highest level and, on the other hand, it is a counter-stigmatization which symbolizes what is central in these relations, that is, the radical reversal of power differential and exclusion of prestigious social functions until then almost exclusively in favor of individuals and social groups of the highest level.

\section{VIII}

In the context of Hispanic America the creation of a forum of discussions around the political equality of free and freed Afro-descendants - which were collectively designated by the "castes" sign of strengthening- became possible in 1810 thanks to the emergency of the Cortes Generales $y$ Extraordinary de la Nación Española. However, the discussions held in September 1811 led to the indefinite postponement of this demand. According to article 22 of the Spanish Constitution of 1812, "los españoles que por cualquier línea son habidos y reputados por originarios del África, les queda abierta la puerta de la virtud y del merecimiento para ser ciudadanos".

At the same time, the article provided that "las Cortes concederán carta de ciudadano a los que hicieren servicios calificados a la Patria, o a los que se distingan por su talento, aplicación y conducta", as long as such Afro-descendants "sean hijos de legítimo matrimonio de padres ingenuos; de que estén casados con mujer ingenua, y avecindados en los dominios de las Españas, y de que ejerzan alguna profesión, oficio o industria útil con un capital propio". Such restrictions, combined with the postponement to an uncertain and undefined future, made political equality within the Spanish Empire practically impossible to thousands of free Afro-descendants and totally impossible to freed Afro-descendants. ${ }^{69}$

Such a decision of the Courts, however, did not affect the entire Spanish Empire the same way. As we all know, after 1810, two main and 
CHUST, Manuel. Reflexões sobre as independências ibero-americanas. Revista de História, n. 159, 2008, pp. 243-262.

71

CHILDS, Matt D. "A black french General arrived to conquer the island". Images of the Haitian Revolution in Cuba's 1812 Aponte Rebbelion". In: GEGGUS, David P. (org.). The impact of the Haitian Revolution..., Op. Cit., pp. 135-156; CHILDS, Matt D. The 1812 Aponte Rebellion..., Op. Cit., pp. 78-120.

72

MUNFORD, C. J.; ZEUSKE, M. Black slavery, class struggle, fear and revolution in St. Domingue and Cuba, 1785-1795. The Journal of Negro History, vol. 73, n. 1-4, 1988, pp. 12-32; BERBEL, M., MARQUESE, R. B.; PARRON, T. Escravidão e política..., Op. Cit., pp. 175-181.

73

LASSO, Marixa. Myths of harmony..., Op. Cit., pp. 45-46

74

APUNTAMIENTOS para escribir una ojeada sobre la historia de la transformación política de la Provincia de Cartagena. In: CORRALES, Manuel E. (Org.). Documentos para la historia de la Provincia de Cartagena de Indias (Vol. I). Cartagena de Indias: Universidad de Cartagena/ Instituto Internacional de Estudios del Caribe, 2011, p. 201 [1883] effective routes opened at the specific representations that were part of that comprehensive social representation: remain linked to Madrid or follow the path of the insurgency. ${ }^{70}$ On the one hand, in the specific social figuration of the island of Cuba, which opted to remain linked to Madrid, the strength, the pressure and the economic ascension of planters and slave traders linked to the rising sugar plantation had already imposed several legal restrictions to free and freed Afro-descendants after the revolution in Saint-Domingue, which, moreover, tended to be reinforced after the alleged rebellion of Aponte in 1812 - an event in which free and freed Afro-descendants had indeed a more prominent role than the slaves. ${ }^{71}$ Furthermore, their character of stronghold restricted even more the action and mental representations of Republican content then spreading in the social representations of Terra Firme, while Cuba served as a shelter for those who refused to follow the insurgency. ${ }^{72}$

On the other hand, the most numerous free and freed Afro-descendant population of the Spanish Empire was concentrated in the Viceroyalty of New Granada, mainly in the insurgent social representations of the province of Cartagena and the Captaincy General of Venezuela. In these specific social figurations there are emphatic actions of free and freed Afro-descendants in favor of political equality, which led, on the edge, to the break with the comprehensive configuration of the Spanish Empire. This was the case of the province of Cartagena, whose political autonomy was consummated on 11 November 1811. Since the deposition of the last colonial Governor of Cartagena, Francisco de Móntes, in June 1810, was executed by military troops predominantly formed by free and freed Afrodescendants who from then on never tended to disarm themselves, the increasing demand for political equality was reflected in the new electoral legislation of that province. In December 1810 categories of "color" strictly associated with captivity and disgrace in the context of the old or oligarchic type society, appeared alongside other categories associated with the honor and distinction of the birth in the rules then established for the elections to the cabildo and the Government of the province. According to those rules, were able to constitute voters "todos los vecinos del distritos de la parroquia, blancos, indios, mestizos, mulatos, zambos y negros, con tal que sean padres de familia, o tengan casa poblada y que vivan de su trabajo".73 As a witness narrated, "el pueblo de Cartagena", which had begun since then to "sentir la importancia de su dignidad y valimiento", converted into "una masa heterogénea de nobles, de plebeyos". There was, among them, on the one hand, "hombres orgullosos engreídos los unos con su nacimiento, otros con sus grandes riquezas" and, on the other hand, "otros envilecidos en los ofícios mecánicos, que en el regimen colonial eran mirados con desprecio: este pueblo, digo, va a presentarse en el teatro del mundo, dirigiendo su suerte y sus destinos, dandose leyes e instituciones para su felicidade".74

In fact, after that province becoming an independent Republic of the comprehensive social representation of the Spanish Empire, a legislative body was elected to which at least three free Afro-descendants - Pedro Romero, Cecilio Rojas and Remígio Marquez - were elected. This body had the task of elaborating the Constitution of the State of Cartagena de Indias, signed on 15 June 1812, in which can be observed in Title IX, article 2, the guarantee of citizenship to every "hombre libre, vecino, padre o cabeza de familia" and "sin dependencia de otro", regardless, therefore, of their "col- 
CONSTITUCIÓN del Estado de Cartagena de Indias sancionada por la Convención General en 14 de junio de 1812. Cartagena: Imprenta del C. Diego Espinosa, 1812, pp. 153, 164; HELG, Aline. The limits of equality..., Op. Cit., pp. 22-23.

76

GÓMEZ, Alejandro E. Las revoluciones blanqueadoras, elites mulatas haitianas y "pardos beneméritos" venezolanos, y su aspiración a igualdad, 1789-1812. Nuevo Mundo, Mundos Nuevos, n. 5, 2005, p. 6

77

HELG, Aline. The limits of equality..., Op. Cit., p. 21.

78

HELG, Aline. Simón Bolivar and the spectre of "pardocracia": José Padilla in post-independence Cartagena. Journal of Latin American Studies, vol. 35, n. 3, 2003, p. 449

79

HELG, Aline. Simon Bolivar's Republic: A Bulwark Against The "Tyranny" Of The Majority. Revista de Sociologia e Política, vol. 20, n. 42, 2012, pp. 21-37. or" and, more important, their former relationship with captivity. ${ }^{75}$ In turn, the Federal Constitution of Venezuela of December 1811, in clear response to the ongoing discussions in Spanish Courts revoked all "las leyes que imponían degradación civil a una parte de la población libre de Venezuela conocida hasta ahora bajo la denominación de pardos".76 At the same time, the demand for political equality is present in various representations produced by free and freed Afro-descendants of New Granada in the early decade of 1810. The Libros de bautismo de pardos y morenos of the Archbishopric of Cartagena for the years 1811 to 1819 , for example, contain numerous records of fathers, mothers, godfathers and godmothers whose names were proceeded by "citizen", in a clear allusion to the new condition of the individuals of that social group in the democratic and representative type society in formation. ${ }^{77}$ Finally, the first Constitution of Gran Colombia, elaborated in 1821, guaranteed "freedom, security, prosperity and equality" to all individuals, and unlike what proceeded in the "first independence" (1811-1814), the signs of strengthening related to the color disappeared from all laws, censuses and legal documents. ${ }^{78}$

However, between the decades of 1820 and 1830, during the process of formation of the democratic and representative type society, first in the wide social figuration of Gran Colombia and after in the specific representations of Colombia, Venezuela and Ecuador, the political equality of free and freed Afro-descendants was object of discussions and disputes, forging a tension field involving former outsiders and established, or individuals and social groups of the lowest and highest levels. Around 1815, well before independence, therefore, the most prominent political leader of future Gran Colombia, Simón Bolivar, had already expressed that, although the "white race" was demographically a minority, it "had intellectual capabilities which conferred them relative equality" with the majority of the population formed by free and freed Afro-descendants. Between 1821 and 1826, Bolivar coined the concept of pardocracia in his private letters, which tended to express his fear of a "Government of Browns" within the rising Republic. "La igualdad legal", he wrote to Santander in April 1825, "no es bastante para el espíritu que tiene el pueblo, que quiere que haya igualdad absoluta, tanto en lo público como en lo doméstico; y después querrá la pardocracia, que es la inclinación natural y única, para exterminio después de la clase privilegiada".79

On the other hand, it was common in those years not only in the rising Hispanic American republics, but also in Imperial Brazil, as I will demonstrate later, that Afro-descendants whose individual history had been deeply affected upwardly by the structural transition process from the old or oligarchic type society to the democratic and representative type, were strongly attacked in the public space through articles written by anonymous authors. Signs of strengthening were evoked in these articles in the context of disputes for prestigious social functions, which were in the democratic and representative type society in formation, apparently processed in an impersonal and detached way as a result of existing legal landmarks. In November 1824, General José Prudencio Padilla, a free Afrodescendant born in 1778 in Riohacha, in the Colombian Caribbean, raised clearly what he understood by "political equality" in reply to the "defamation" perpetrated through an article. The "antiguas familias", he wrote on that occasion, "que por sus atrocidades contra los desgraciados indios, su rapiña, su usura y su monopolio amontonaron riquezas" undermined 
80

HELG, Aline. Simon Bolivar's Republic..., Op. Cit. pp. 29-30; HELG, Aline. Simón Bolivar and the spectre of "pardocracia"..., 0p. Cit., pp. 462-464.

81

LASSO, Marixa. Race War and Nation in Caribbean Gran Colombia, Cartagena, 1810-1832. The American Historical Review, vol. 112, n. 2, 2006, pp. 336-361.

82

ELIAS, Norbert; SCOTSON, John L. Op. Cit., p. 32. "el santo edificio de la libertad y de la igualdad del pueblo, para levantar sobre sus ruinas el tablado de la ambición, y sustituir a las formas republicanas las de sus antiguos privilegios y dominación exclusiva". Driven to emotional destabilization often disregarded as a sociological fact by social scientists, Padilla, when making such arguments, provided his opponents, among them Bolivar himself, to accuse him of promoting a "racial war". As another member of his social group, Manuel Piar, executed under the order of Bolivar in 1817 for "challenging their supremacy and reportedly mobilizing blacks against whites", as Aline Helg writes. Padilla was executed in October 1828 along with other thirty free and freed Afro-descendants "for a conspiracy he did not plan and for a murder he did not commit" as Aline Helg also pointed out. ${ }^{80} \mathrm{His}$ social position and the structure of power relations prevailing then explain, however, his physical elimination.

At the same time, it is worth mentioning that, throughout the decade of 1830, the emergence of associations constituted by free and freed Afro-descendants became impossible, as well as the accusation of "racism", in the context of the Colombian Republic. Marixa Lasso formulates that in Colombia, in these years, "the explicit expression of racial injustice became a mark of unpatriotic division", creating immense difficulties to "fight against prejudice and informal discrimination in a cultural environment that had made a taboo of the complaint of racism".81 I reiterate, however, that it is not the peripheral manifestation of "racism" which is at the heart of the debate, but "the power differentials and the exclusion of the less powerful group of positions with greater potential of influence" - a structural aspect of many established-outsiders relations, regardless of the "color" of individuals and the nature of social groups in dispute. ${ }^{82}$

\section{IX}

The political equality of free and freed Afro-descendants was finally placed on the agenda in the context of the comprehensive social representation of the first Portuguese Empire in the General and Extraordinary Courts of the Portuguese Nation between 1821 and 1822, and then in the Constituent Assembly of the Empire of Brazil, in 1823. The discussions on this topic took place in Lisbon in April and in August 1822. On April 17 of that year they discussed the indication of the peninsular Deputy Manoel Gonçalves de Miranda, representative of Trás-os-Montes, according to which only free Afro-descendants should have the right to vote, excluding therefore the freed Afro-descendants from any access to citizenship. Some deputies of Brazil, such as Francisco Villela Barbosa, representative of Rio de Janeiro, agreed with the indication, but finally the contrary position to this exclusion prevailed, according to the majority of the present deputies. However, this proposal was on the agenda again in August 1822, when Brazilian deputies attempted to establish the separation between active and passive citizens within the Portuguese constituent. At the session of 13 August 1822 it was once again to the deputy of Rio de Janeiro, Francisco Villela Barbosa, to propose that "were ineligible all those who had obtained manumission". The deputies, who gave their favorable opinion to his proposal, were all from Brazil, while the peninsular deputies were opposite to it. ${ }^{83}$

In the arguments in favor and against political equality of freed Afro-descendants, the revolution in Saint-Domingue was remembered twice, once to oppose it and another to endorse it, and ancestral links 
CONSTITUIÇÃO Política do Império do Brasil. Coleção das Leis do Império do Brasil (1824, parte $\left.1^{\mathrm{a}}\right)$. Rio de Janeiro: Imprensa Nacional, 1886, pp. 7-31. with captivity, and not "color", got outstanding role along the discussion. The peninsular Marino Miguel Franzini, deputy for Estremadura, argued against the proposal remembering that the exclusion of free and freed Afro-descendants of the right to active citizenship played a central role in the conflagration of Saint-Domingue: "and serve as example what we have seen on an island of America: and in this case these men shall be excluded, only because they have got the macula imposed by an unjust and barbarian law, which is that of slavery?". In turn, the Deputy of Brazil, Manuel do Nascimento Castro e Silva, representative of the province of Ceará, voted in favor of the denial of political equality to freed Afro-descendants under the argument that "I feel horrified of the disastrous consequences of such a decision, it seems to me that I foresee the sad scenes from the island of S. Domingos, because there is nobody that ignores the influence that this class has on slavery - very easy to seduce". For Castro e Silva, therefore, freed Afro-descendants would be very close to captivity, and could, according to his interpretation, "seduce" the slaves to the revolution as they supposedly had done in Saint-Domingue. The Deputy of Ceará, as many modern historians, ignored, therefore, that the social position of freed Afro-descendants in the freedom-slavery continuum was far from resembling that of slaves. Thus, members of the specific representation of Brazil insisted on introducing a distinction between active and passive citizens in the constitutional text as regards the Portuguese Empire's comprehensive social figuration in order to prevent the political equality of freed Afro-descendants. However, in minority, they were defeated. Under the final terms of the Portuguese Constitution of 1822 not only free Afro-descendants, but also freed became full citizens, while there were not introduced distinctions between active and passive citizens. ${ }^{84}$

Finally, both in the debates of the Assembly of Rio de Janeiro, ended abruptly by the Emperor in November 1823, and, after, in the Constitution of the Empire of Brazil, imposed on the provinces in March of the following year, prevailed the view defended by the deputies of Brazil in Lisbon. On the one hand, the distinction between active and passive citizens was established and, on the other hand, freed Afro-descendants were reduced to the status of passive citizens. Therefore, under article 6 of the Constitution of the Empire of Brazil, "are Brazilian citizens" the ones "who have been born in Brazil, whether naïve or freed, even if the father is a foreigner, since the same does not live here for his Nation's service". However, under article 94 the "freed" were excluded from the right to be "voters, and vote in the election of Deputies, Senators, and Members of Provincial Councils". Since they would not be second-level voters they would not be eligible. ${ }^{85}$ Therefore, as I have observed before, the disqualification of freed Afrodescendants remained in the democratic and representative type society in formation in Brazil's social figuration.

\section{$x$}

Throughout the Decade of 1830, after years of restriction of public space in the first reign, several Afro-descendants were able to express their opinion about the disqualification of Freedmen included in the Constitution and with respect to some consequences of this constitutional restriction to the universality of political equality to the Freemen. On 25 August 1832, for example, the free Afro-descendant Antônio Pereira Rebouças, a son of a Freedwoman who had become a deputy of the Empire, noted during a 
86

ANAIS do Parlamento Brasileiro. Câmara dos Senhores Deputados. Rio de Janeiro: Tipografia Imperial e Constitucional J. Villeneuve, 1879, pp. 200-201; MATTOS, Hebe. Escravidão e cidadania no Brasil monárquico. Rio de Janeiro: Jorge Zahar Editores, 2000, pp. 35-49. parliamentary debate that, according to the Constitution of 1824, one of "the negative conditions of the voting for elector is not having been born naïve", that is, being born a slave and, intra-generationally, become liberated. Rebouças considered the relegation of Freedmen to the condition of second-class citizens a "hateful, contradictory and impracticable exception", which was, at that moment, to be expanded. The proposal, written by the feather of Deputy Miguel Calmon du Pin e Almeida, his colleague from the same province of Bahia, predicted that "officers of the national guards can only be voted those who can be voters". For Rebouças this was an "unconstitutional" measure, since the Magna Carta had excepted "Brazilian citizens who were born naïve to be parish, provincial councilor, Deputy, Senator and State Councilor voters; and with this exception established the general rule to the contrary". According to this reasoning, continues Rebouças, "non-naïve citizens can serve all the jobs for which they consider themselves enabled by their talents and virtues". "And", he explains, "it is an absurd that, according to the Constitution, freed citizens can be members of the Regency, and that it is denied to them to be elected officer of the national guards".86

Rebouças' speech refers, moreover, not only to connection, recurrences and structural regularities plans, but also to the cross-references mobilized by free and freed Afro-descendants about different connected processes occurred in specific social representations that were part of the comprehensive configuration of the Atlantic world. Adding to his arguments effective knowledge about Saint-Domingue and about the Colombian Caribbean, Rebouças stressed at that time that if "the edict of Luiz XIV, dated at Versailles in March 1685", that is, the Code Noir, "was fulfilled in the respective part considering French and capable of all jobs and occupations the Freedmen of the colonies" and if proposed measures "in the constituent and more assemblies that followed" had been fulfilled "the refractory and obstinate settlers would not suffer so much, nor would the scenes of terror and atrocity take place that make the hair stand up only appearing to the imagination!". Surely his words were echoes of the formulations of Julien Raymond uttered during the Decades of 1780 and 1790, then an uncompromising defender of the reintroduction of the principles of the Code Noir in the specific social representation of Saint-Domingue. At the same time, Rebouças remembered that among "our Spanish American neighbors of New Granada, Venezuela, Peru, Mexico", some free and freed Afro-descendants "have been seen in the group of the first generals, of the number of the liberators and provincial chiefs, one Arismendy, one Piar, one Paez, one Padilla, one Sant'Anna and many others that I do not have to nominate".87 However, at least two of these Afro-descendant generals - Piar and Padilla - had been executed, as we have seen, thanks to the absolutely unfounded fear, in fact, of the "racial war" and of "pardocracia". In general, as I have been pointing out throughout this article, the knowledge displayed by Rebouças and other free and freed Afro-descendants of the Atlantic world about the destiny of other individuals of the same social group who lived in separate colonial empires of theirs, were uninterested and detached, but, before, had the practical function of supplying disputes fought in the tension field of their own social representation. Despite his arguments and his Atlantic perspective, Rebouças watched, in August 1832, the defeat of his counterproposal, which was, at the same time, the defeat of the universalization of political equality to freed Afrodescendants of the Empire of Brazil. 
88

O Brasileiro Pardo, n. 1, Rio de Janeiro, 21 October 1833.

89

PINTO, Ana Flávia Magalhães. De pele escura e tinta preta: a imprensa negra do século XIX (1833-1899). Dissertation (Master in History). Instituto de Ciências Humanas da Universidade de Brasília, Brasilia D.F., 2006, p. 17, 51-54

90

O Brasileiro Pardo, n. 1, Rio de Janeiro, 21 October 1833.

91

O Mulato ou 0 Homem de Cor, n. 5, Rio de Janeiro, 12 June 1833.
However, Rebouças was not alone. "We the Browns", says the only issue of Brasileiro Pardo, of 21 October 1833, "with the exception of the freed from the National Guard, have been reduced to not being allowed to belong to them, except those of us who were born free: the adoptive", that is, the Portuguese, "of whom they had taken the guns, on whom they had thrown us on the nights of March, were all armed!".88 More ironic and less solemn than the noble deputy of Bahia, the writers of $O$ Brasileiro Pardo and $\mathrm{O}$ Mulato ou $\mathrm{O}$ Homem de Cor - this printed in the typography belonging to free Afro-descendant Francisco de Paula Brito ${ }^{89}$ - pointed at the same time to formal or informal practices of monopolization of prestigious social functions, according to them, in upward trend in the decade of 1830. The Regency often presented as the culmination of the process of formation of the democratic and representative type society in Brazil, was represented in these newspapers as a phase of regression on the universalization of social equality for free and freed Afro-descendants. "When the Duke of Bragança was Emperor of Brazil", is said in the same newspaper, there were "in the public offices, the Ministry, and even in the Chamber of Senators some Browns; and to see that the Emperor did not forget them even for the imperial house, and that he treated them well, gave them patents, awards, etc.". In the Regency, inversely, "many employees were dismissed without crime, without process, and 'à turca'".90 In turn, in the newspaper 0 Mulato ou 0 Homem de Cor, in its edition of 4 November 1833, they denounce that "when we said that they chase the men of color, shout the chimangos, present evidence! And when we give them to the public they soon ridicule. His example was represented by the case of an individual, Candido de Assis, War Arsenal employee in Rio de Janeiro, which would confirm the current trend. He had been a War Arsenal employee for four years, and for two years he had offered "free service in place of practitioner". When, after the staff reform, all except Assis received significant raises, this sent request "to the House of Representatives to undo the mistake". However, contrary to what he expected, "break out the Decree of Honorable Regency dismissing him of the position he had at the Arsenal, without saying the cause of his dismissal". It is stated clearly in O Mulatto that "it has been a long time since Mr. Candido should expect his dismissal, because in 1828 when he joined the Arsenal, there had been a war about him being mulatto." Furthermore, another employee, Thomaz José de Aguilar, connected to the relatives and oligarchic networks of the Regency, was accused of leaving the "Arsenal for two years receiving his salary, just because he did not want to be in a Division with mulattos".91 As I formulated before, once within the democratic and representative type society, the social tension field is more open and more horizontal, power relations and disputes for prestigious social functions, apparently processed in an impersonal and detached way as a result of existing legal landmarks, can be punctuated by any recurrences to "signs of strengthening" - such as skin color or ways to talk and behave publicly. Social destinies of specific human beings can be defined by relations of power merged with socio-dynamics of stigmatization.

This was also the situation faced, in February 1837, by the Afrodescendant major Felipe Emiliano Benício Mundrucu, when he returned to Pernambuco after more than ten years of exile. Militant in the revolution of 1817 and mainly in the Confederation of Ecuador, Mundrucu had been arrested along with Frei Caneca and another free Afro-descendant, 
Manifiesto que hace a la Nación Colombiana Emiliano Felipe Benicio Mundrucu, Mayor Comandante de Segundo Batallón de Cazadores de la División Republicana de Pernambuco, dirigido al respetable publico y ejército de la República de Colombia. In: Chacon, Vamireh. Da Confederação do Equador à Grã-Colômbia. Brasília: Senado Federal, 1983, p. 198.

93

Comunicado. Diário de Pernambuco, n. 41 Recife, 20 February 1837.

94

Correspondência. Diário de Pernambuco, n. 79, Recife, 11 April 1837.
Agostinho Cavalcante e Souza, in the last battles against the Empire in December 1824. Sentenced to death, as Caneca and Souza, who were executed, Mundrucu managed to escape to Boston, in the United States, following from there to Haiti. Finally, in 1826, he moved to Gran-Colombia, where he campaigned until his return to Pernambuco in the decade of 1830 in the troops of José Antonio Paez, the same Afro-descendant General referenced by Rebouças. ${ }^{92}$ In February 1837, Mundrucu was appointed commander of one of the fortresses of Recife, the Brum, by the Regency Government, but his mandate was prevented by the then President of the province of Pernambuco, Vicente Tomás Pires de Figueiredo de Camargo. On 20 February 1837 an anonymous letter was published in the Diário de Pernambuco supporting the President's decision. In this, reprising the episode lived by Prudêncio Padilla almost ten years before, they claimed that Mundrucu had only been "Captain of a Company of the Militia Battalion of Browns of this city" and, therefore, had "no qualification, no military school"; once "not being Major in the First Line, he was not qualified for such a command". One of the objections of the anonymous author was formulated by reversing the recurrence to the signs of strengthening: "there are individuals", he writes, "that claim no other merit otherwise the color, as if this should be a privilege to obtain jobs for which neither their qualifications, nor the concept they deserve to the public in any way qualify them".93 Therefore, the anonymous author reversed the centuries-old social stigma imposed on free and freed Afro-descendants by individuals and social groups of the highest level and transformed, through his sophisticated argument, the complaint of discrimination based on the sign of strengthening of the color into "privilege".

In his defense, published in the same newspaper on 11 April 1837, Mundrucu accused the anonymous author of "depressing both my Civil and military reputation", and added that he had been named "Sergeant Major of First Line" in October 1823, at the same time that he argued that he was not the "only First Line Officer of the Army that had its origin in the Militias". His main argument, however, consisted of articulating the Constitution of the Empire with the political equality. According to Mundrucu, the "Central Government, faithful to the Constitution, Article 179" wanted to see disappear "the losses of Classes, or Colors". However, the anonymous author "and others of his iniquitous feelings" did not want to "willingly see a Brown Officer in a place of distinction; it seems that in the feeling of these they only judge the Browns and Blacks capable in times of crisis and danger". ${ }^{94}$ Article 179 of the Constitution of 1824, which was also on the front page of every issue of $\mathrm{O}$ Mulato ou $\mathrm{O}$ Homem de Cor, determined that "any citizen can be admitted to public office, Political and Military positions without other difference that is not of their talents and virtues". For free and freed Afro-descendants, considering the trajectory of their social group since the old or oligarchic type society, marked by the notions of honor and birth and the monopolization that individuals of the highest level exercised around the prestigious social functions, this article seemed to be a dead letter, therefore, in the context of the democratic and representative type society that succeeded it. In this, the socio-dynamics of stigmatization maintained its course, despite the legal and political changes in the status of free and freed Afro-descendants - now made equal in front of the other individuals. 
95

ELIAS, Norbert; SCOTSON, John L. Op. Cit., pp. 26-27.

96

Idem, p. 31.
The permanence of slavery and slave trade in Brazil's imperial representation - an explicit demand of both individuals and social groups of the highest level and those of the elite of the lowest social level formed by free and freed Afro-descendants - was to the last, a double-edged sword. After all, if on the one hand, slavery marked up their ascending status position in the freedom-slavery continuum, on the other hand it fastened them to the ancient and eternal chains of captivity due to the peripheral sign of their "color". "The concepts used by the groups established as means of stigmatization," write Elias and Scotson, "may vary according to the social characteristics and traditions of each group".

In many cases, there is no sense outside the specific context in which they are employed, but, nevertheless, they hurt the outsiders deeply, because the established groups tend to find an ally in an inner voice of their social inferiors".95 Such concepts or signs of strengthening, thus, referring to the emotional dimension of the outsiders and their low self-esteem, aim to weaken them during disputes verified in the tension field of their specific social figuration. The social results of these recurrences, moreover, are devastating the intergenerational perspective, since "growing up as a member of a stigmatized outsider group may result in specific intellectual and affective deficits".96

Thus, a figurational analysis, that is, incorporating all social levels and all individuals and groups of a same representation, clearly shows the mistake of limiting the examination of the question of political equality to the political-legal sphere or just to the field of intentions of groups and individuals of the highest level. Finally, it should be emphasized that the social position of outsiders and the inter-generational connection of free and freed Afro-descendants with captivity, much more important, analytically speaking, then their "color", and, on the other hand, the immense differential of power retention of individuals and established social groups, situated at the highest level, were persistent aspects in the formation of the democratic and representative type society in specific social representations once belonging to the French, Portuguese and Spanish Empires. In these, formal or informal practices of monopolization of prestigious social functions followed their course and even tended to increase after abolitions.

\section{Bibliography}

ANNEQUIN, J. et. al. (org.). Formas de exploração do trabalho e relações sociais na Antiguidade clássica. Lisboa: Estampa, 1978.

BERBEL, M., MARQUESE, R. \& PARRON, Tâmis. Escravidão e politica. Brasil e Cuba, 1790-1850. São Paulo: Hucitec/FAPESP, 2010.

BLACKBURN, Robin. A construção do escravismo no Novo Mundo. Do barroco ao moderno (1492-1800). Rio de Janeiro: Record, 2003. . Haiti, Slavery, and the Age of the Democratic Revolution. William and Mary Quarterly, vol. 63, nº 4, 2006, pp. 643-674.

BUCKLEY, Roger N. Slave or freedman: the question of the legal status of the British West India soldier, 1795-1807. Caribbean Studies, vol. 17, no 3-4, 1978, pp. 83-113.

CANDIDO, Mariana P. South Atlantic Exchanges: The Role of Brazilian-Born Agents in Benguela, 1650-1850. Luso-Brazilian Review, vol. 50, no 1, 2013, pp. 53-82.

CANDIOTI, Magdalena. Altaneros y libertinos. Transformaciones de la condición juridica de los afroporteños en la Buenos Aires 
revolucionaria. Desarrollo Economico, vol. 50, n 198, 2010, pp. 271-296.

CHACON, Vamireh. Da Confederação do Equador a Gra-Colombia. Brasília: Senado Federal, 1983.

CHAMOSA, Oscar. "To honor the ashes of their forebears": the rise and crisis of African Nations in the Post-Independence State of Buenos Aires, 1820-1860. The Americas, vol. 59, no 3, 2003, pp. 347-378

CHAVES, C. M. das G.; SILVEIRA Marco A. (orgs.). Território, conflito e identidade, Belo Horizonte/Brasília: Argumentum/CAPES, 2007.

CHILDS, Matt D. The 1812 Aponte Rebellion in Cuba and the Struggle against Atlantic Slavery. Chapel Hill: The University of North Carolina Press, 2006.

CHUST, Manuel. Reflexões sobre as independências ibero-americanas. Revista de Historia, no 159, 2008, pp. 243-262.

CORRALES, Manuel E. (Org.). Documentos para la historia de la Provincia de Cartagena de Indias (Vol. I). Cartagena de Indias: Universidad de Cartagena/Instituto Internacional de Estudios del Caribe, 2011.

DANTAS, Mariana L. R. "For the benefit of the common good": Regiments of caçadores do mato in Minas Gerais, Brazil. Journal of Colonialism and Colonial History, vol. 5, n० 2, 2004.

DUNNING, Eric; HUGHES, Jason. Norbert Elias and modern Sociology. Knowledge, interdependence, power, process. London: Bloomsbury Publishing, 2013.

ELIAS, Norbert; SCOTSON, John L. Os estabelecidos e os outsiders. Sociologia das relações de poder a partir de uma pequena comunidade. Rio de Janeiro: Jorge Zahar Editor, 2000.

ELIAS, Norbert. A sociedade de corte. Investigação sobre a sociologia da realeza e da aristocracia de corte. Rio de Janeiro: Jorge Zahar Editor, 2001. . Envolvimento e distanciamento. Estudos sobre sociologia do conhecimento. Lisboa: Dom Quixote, 1997.

. Escritos \& ensaios. Rio de Janeiro: Jorge Zahar Editora, 2006. . Introdução a sociologia. Lisboa: Edições 70, 2005.

. O processo civilizador (vol. 1). Rio de Janeiro: Jorge Zahar Editor, 1994. . Sobre o tempo. Rio de Janeiro: Jorge Zahar, 1998.

FRAGOSO, João, et. al. (orgs.). Arquivos paroquiais e historia social na America Lusa, seculos XVII e XVIII: métodos e técnicas de pesquisa na reinvenção de um corpus documental. Rio de Janeiro: Mauad X, 2014. ., et. al. (orgs.). $O$ antigo regime nos tropicos. A dinâmica imperial portuguesa (Séculos XVI-XVIII). Rio de Janeiro: Civilização Brasileira, 2001.

GARRIGUS, John D. Before Haiti: race and citizenship in French SaintDomingue. New York: Palgrave Macmillan, 2014.

GEGGUS, David P.; FIERING, Norman (orgs.). The World of the Haitian Revolution. Bloomington: Indiana University Press, 2009.

GEGGUS, David P. Haitian revolutionary studies. Bloomington: Indiana University Press, 2002.

GÓMEZ, Alejandro E. ¿Ciudadanos de color? El problema de la ciudadanía de los esclavos y Gente de Color durante las revoluciones francoantillanas, 1788-1804. Anuario de Estudios Bolivarianos, vol. $\mathrm{XI}, \mathrm{n}^{\circ} 12,2005$, pp. 138-139

. Las revoluciones blanqueadoras, elites mulatas haitianas y "pardos beneméritos" venezolanos, y su aspiración a igualdad, 1789-1812. Nuevo Mundo, MundosNuevos, n 5, 2005, p. 6 
HELG, Aline. Simón Bolivar and the spectre of "pardocracia": José Padilla in post-independence Cartagena. Journal of Latin American Studies, vol. 35, no 3, 2003, p. 449

. Simon Bolivar's Republic: A Bulwark Against The "Tyranny" Of The Majority. Revista de Sociologia e Politica, vol. 20, no 42, 2012, pp.21-37. . The limits of equality: Free people of colour and slaves during the first independence of Cartagena, Colombia, 1810-1815. Slavery \&t Abolition, vol. 20, n 2, 1999, p. 13

INGERSOLL, Thomas N. Free Blacks in a Slave Society: New Orleans, 17181812. William and Mary Quarterly, vol. 48, no 2, 1991, pp. 173-200

KOPYTOFF, I. Slavery. Annual Review of Anthropology. Vol. 11, 1982, pp. 207-230

KLEIN, Herbert S., The Colored Freedmen in Brazilian Slave Society, Journal of Social History, vol. 3, no 1, 1969, pp. 30-52;

KRAAY, H. Race, State and armed forces in independence-era Brazil (Bahia, 1790s-1840s). Stanford: Stanford University Press, 2001.

LARA, S. H. Fragmentos setecentistas. Escravidao, cultura e poder na America portuguesa. São Paulo: Cia. das Letras, 2007. - Palmares \& Cucau: 0 aprendizado da dominação. (Tese apresentada para o concurso de Professor Titular Área de História do Brasil). Instituto de Filosofia e Ciências Humanas da UNICAMP, Campinas, 2008.

LASSO, Marixa. Myths of harmony. Race and republicanism during the Age of Revolution, Colombia, 1795-1831. Pittsburgh: University Of Pittsburgh Press, 2007. . Race War and Nation in Caribbean Gran Colombia, Cartagena, 18101832. The American Historical Review, vol. 112, n² 2, 2006, pp. 336-361.

LIMA, Priscila. De libertos a habilitados. Interpretações populares dos alvarás antiescravistas na América portuguesa (1761-1810). Dissertação (Mestrado em História). Setor de Ciências Humanas, da UFPR, Curitiba, 2011.

MARAVALL, José Antonio. Poder, honor y elites en el siglo XVII. Madrid: Siglo XXI, 1989

MCALISTER, L. N. The "fuero militar" in New Spain. Gainesville: University of Florida Press, 1957.

MIERS, Suzanne; KOPYTOFF, Igor (orgs.). Slavery in Africa. Historical and anthropological perspectives. Madison: The University of Wisconsin Press, 1979.

MÚNERA, Alfonso. El fracaso de la nacion. Bogotá: Editorial Planeta Colombiana, 2008.

MUNFORD, C. J.; ZEUSKE, M. Black slavery, class struggle, fear and revolution in St. Domingue and Cuba, 1785-1795. The Journal of Negro History, vol. 73, no 1-4, 1988, pp. 12-32

PATTERSON, Orlando. Slavery and Social Death: A Comparative Study. Cambridge: Harvard University Press, 1982.

PINTO, Ana Flávia Magalhães. De pele escura e tinta preta: a imprensa negra do século XIX (1833-1899). Dissertação (Mestrado em História). Instituto de Ciências Humanas da Universidade de Brasilia, Brasilia D.F., 2006.

RAMINELLI, Ronald. Impedimentos da cor. Mulatos no Brasil e em Portugal, c. 1640-1750. Varia Historia, vol. 28 , n 48, 2012, pp. 699-723. . "Los límites del honor". Nobles y jerarquias de Brasil, Nueva España y Peru, siglos XVII y XVIII. Revista Complutense de Historia de America, vol. 40, 2014, pp. 45-68. 
. Nobreza e riqueza no Antigo Regime Ibérico setecentista. Revista de Historia. Vol. 169, n² 2, 2013, pp. 83-110.

RIBEIRO, Gladys Sabina. 0 desejo da liberdade e a participação de homens livres pobres e "de cor" na independência do Brasil. Cadernos CEDES, vol. 22, no 58, 2002, p. 32;

RODRIGUES, Eugénia. Cipaios da Índia ou soldados da terra? Dilemas da naturalização do exército português em Moçambique no século XVIII. História Questões e Debates, vol. 45, n² 2, 2006, pp. 57-95;

RUSSELL-WOOD, A. J. R. Ambivalent Authorities: The African and AfroBrazilian contribution to local governance in Colonial Brazil. The Americas, vol. 57, no 1, 2000, pp. 13-36

. Escravos e libertos no Brasil colonial. Rio de Janeiro: Civilização Brasileira, 2005.

SCAMMELL, G. V. Indigenous assistance in the establishment of Portuguese power in Asia in the sixteenth century. Modern Asian Studies, vol. 14, $\mathrm{n}^{\circ} 1,1980$, pp. 1-11

SILVA, Luiz Geraldo; SOUZA, Fernando Prestes. Negros apoyos. Milicianos afrodescendientes, transición política y cambio de estatus en la era de las independencias (capitanías de São Paulo y Pernambuco, Brasil, 1790-1830). Nuevo Mundo-Mundos Nuevos, v. 2, 2014, p. 1-25.

SILVA, Luiz Geraldo. "Esperança de liberdade". Interpretações populares da abolição ilustrada (1773-1774). Revista de Historia, vol.144, 2001, pp. 107-150;

- Gênese das milícias de pardos e pretos na América portuguesa: Pernambuco e Minas Gerais, séculos XVII e XVIII. Revista de Historia (USP), v. 169, no 2, 2013, pp. 111-144.

. Negros de Cartagena y Pernambuco en la era de las revoluciones atlánticas: trayectorias y estructuras (1750-1840). Anuario Colombiano de Historia Social y de la Cultura, v. 40, n² 2, 2013, p. 211-240.

. Religião e identidade étnica. Africanos, crioulos e irmandades na América portuguesa. Cahiers des Ameriques Latines, vol. 44, n 3, 2003, pp. 77-96.

TOMICH, Dale. Atlantic History and World Economy: concepts and constructions. Proto Sociology, vol. 20, 2004, pp.102-121

VOELZ, Peter M. Slave and soldier. The military impact of Blacks in the colonial Americas. New York: Garland Publishing, 1993, pp. 3-9.

\section{DOCUMENTAL}

ANAIS do Parlamento Brasileiro. Camara dos Senhores Deputados. Rio de Janeiro: Tipografia Imperial e Constitucional J. Villeneuve, 1879, pp. 200-201; MATTOS, Hebe. Escravidao e cidadania no Brasil monarquico. Rio de Janeiro: Jorge Zahar Editores, 2000, pp. 35-49.

Aviso do secretário de estado da Marinha e Ultramar, Tomé Joaquim da Costa Corte Real, ao presidente do Conselho Ultramarino, marquês de Penalva D. Estevão de Meneses, ordenando que se consulte a solicitação dos capitães e mais oficiais do terço dos Henriques da guarnição da Bahia para que só se nomeie os crioulos nacionais para os lugares de oficiais do dito Terço, da mesma forma como se pratica em Pernambuco, onde o terço foi criado. AHU-BA, cx. 137 doc. 77. Belém, 3 de dezembro, de 1756.

Carta do governador da capitania de Pernambuco, Duarte Sodré Pereira Tibão, ao rei D. João $V$, informando não haver necessidade de corpos 
separados de pardos e negros, sugerindo a extinção dos postos de mestre de campo e sargento mor dos mesmos, assim como o de governador dos índios.. AHU-PE, cx. 42, doc. 3797. Recife, 10 de março de 1732.

Carta régia proibindo a existência de corpos separados de pardos e bastardos. Documentos Interessantes para a Historia e Costumes de São Paulo. Vol. XXIV, s/d, p. 43-44

Comunicado. Diario de Pernambuco, n 41, Recife, 20 de fevereiro de 1837.

Consulta do Conselho Ultramarino ao príncipe regente D. João, sobre a representação dos Homens Pardos da capitania de Goiás, solicitando a admissão ao serviço das Câmaras da capitania, em qualquer emprego público, por possuírem as habilitações necessárias, não obstante sua cor.. AHU-GO, cx. 47, doc. 2700. Lisboa, 7 de janeiro de 1804;

CONSTITUIÇÃO Política do Império do Brasil. Colecao das Leis do Imperio do Brasil (1824, parte 19). Rio de Janeiro: Imprensa Nacional, 1886, pp.7-31.

CONSTITUCION del Estado de Cartagena de Indias sancionada por la Convencion General en 14 de junio de 1812. Cartagena: Imprenta del C. Diego Espinosa, 1812, pp. 153, 164

CONSTITUIÇÕES Primeiras do Arcebispado da Bahia. São Paulo: Tipografia 2 de Dezembro de Antônio Louzada Nunes, 1853, p. 93.

Correspondência. Diario de Pernambuco, n 79, Recife, 11 de abril de 1837.

DIARIOS das Cortes Geraes e Extraordinarias da Nacao Portugueza. Legislatura 1, sessão 2, no 11, ata de 13-08-1822, fls. 135 a 146, p. 144.

Expediente sobre la admisión de los hijos de Diego Mejías Bejarano a la Universidad. 1801-1805. Archivo General de Indias, Audiencia de Caracas, legajo 976. Apud: HISTORIA de las ideas pedagogicas en la Venezuela colonial (1767-1821). Fuentes primarias para su estudio modulo aprendizaje. Caracas: s/e, s/d, pp. 1-16.

Informação geral da Capitania de Pernambuco (1749). Anais da Biblioteca Nacional, vol. XXVIII, 1906, p. 456

Jacinto Roque da Rocha, Capitão de Campo da Freguesia do Cabo. Arquivo Público Estatual Jordão Emerenciano (Recife), série Patentes Provinciais, vol. 9, fls. 131v-132, Recife, 17 de novembro de 1797.

Las milicias de Pardos de Caracas solicitan se las provea de vestuario, se las conceda el título de Regimiento y poder comercializar dos mil fanegas de cacao. Archivo General de Simancas (Doravante A.G.S.), Secretaria del Despacho de Guerra, SGU, Leg. 7198, 7, hojas 40-44. Caracas, 17 de agosto de 1767

Livro para matrícula e registro das esquadras dos capitães do mato. Arquivo Público Mineiro, série Câmara Municipal de Sabará, CMS-081, 1788.

O Brasileiro Pardo, n 1, Rio de Janeiro, 21 de outubro de 1833.

O Brasileiro Pardo, no 1, Rio de Janeiro, 21 de outubro de 1833.

O Mulato ou O Homem de Cor, n 5, Rio de Janeiro, 12 de junho de 1833.

Observations sur l'origine et les progres Du prejuge des colons blancs contre les hommes de couleur. Par M. Raymond, Homme de couleur de Saint-Domingue. Paris: Belin, 1791

Quejas de los alcaldes ordinarios de Caracas por la concesión del Fuero Militar a las Milicias de Pardos de Caracas. A.G.S., Fondo Secretaria del Despacho de Guerra, 1762-1765, Leg. 7198,3, hojas 15-24. Caracas, 28 de junho de 1762.

Requerimento de Luís Martins Soares ao rei, D. João, solicitando provisão de requerente supranumerário na cidade da Bahia para entrar no 
número e dispensa nos acidentes das cores pardas por ocasião da oposição. AHU-BA, caixa 79 documento 6557. Cidade da Bahia, 17 de junho de 1744

Requerimento de Paulo Coelho ao rei, D. José I, pedindo provisão para que sua cor parda não lhe sirva de impedimento para exercer qualquer função pública em qualquer parte do Brasil. Pernambuco. AHU-PE, cx. 76 doc. 6377. Recife, 29 de julho de 1754.

Requerimento do capitão Miguel Mendes de Vasconcelos e do seu filho ao rei, D. João, solicitando provisão para servirem de procuradores de causas nos auditórios da cidade da Bahia, sem embargo de serem pardos. Arquivo Histórico Ultramarino (Lisboa), Bahia, (doravante AHU - Capitania correspondente), cx. 77 documento 6412. Cidade da Bahia, 23 de setembro de 1743. 